\title{
SOUTH AFRICAN ASCOMYCETES IN THE NATIONAL HERBARIUM.
}

\author{
By Ethel M. Doidge.
}

\section{Part VI.}

\section{Erikssonia Carissae Doidge nov. spec.}

Perithecia hypophylla, maculis dilute brunneolis usque $10 \mu$ diam., insidentia, laxe v. densiuscule dispersa, immersa, globosa, $75-120 \mu$ diam.; pariete $25-40 \mu$ crasso stromatice e stratis numerosis cellularum tenuiter tunicatarum olivaceo-brunnearum, angulatarum, 5-6 $\mu$ diam. composito, superne cum epistromate connato ; epistroma emergentia, alata, recurvata, plus minus radiatim usque $130 \mu$ diam. producta; ostiolo $20-25 \mu$ longo, haud vel vix prominulo, poro truncato-conico $\mathrm{v}$. cylindraceo, ca. $12-16 \mu$ lato pertuso. Asci cylindracei v. cylindraceo-clatati, 8-spori, superne late rotundati, brevissime pedicellati, 45-55 $\times 6-7 \mu$, tenuiter tunicati, ad apicem leniter incrassati. Sporae distichae, oblongoclavatae, utrinque rotundatae, 1-septatae, hyalinae, 12.5-15 $\times 2-3 \mu$. Paraphyses filiformes, mox mucosae.

Hab. in foliis Carissae bispinosae, Mtunzini prope Eshowe, leg. E. M. Laughton, 33545.

Perithecia on dry, light brown leaf spots, which are circular to irregular in outline and have a raised, dark brown or black line at the margin; hypophyllous, scattered or in small groups, occasionally confluent. Perithecia globose, 75-120 $\mu$ diam., one-half to two-thirds immersed in the leaf tissue ; perithecial wall brown, stromatic, $10-15 \mu$ thick, composed of thin-walled, olive-brown, angular, parenchymatous cells, 5-6 $\mu$ diam. Above, the wall is continuous with the epistroma, which ruptures the epidermis gnd emerges to the leaf surface, growing out, to a diameter of $130 \mu$, into re-curved, more or less radiating strands, each composed of a number of irregular rows of cells; the ruptured epidermis adheres closely to the sides of the epistroma. Externally the wall is connected with hyphae which penetrate into the leaf tissues; these are 5-6 $\mu$ thick, frequently septate and often constricted at the septa. Ostiole 20-25 $\mu$ long, completely merged with the epistroma and not protruding beyond the stromatal wings; traversed by a pore which is truncate-conical to cylindrical and about 10-16 $\mu$ diam. Asci cylindrical to cylindrical-clavate, 8 -spored, broadly rounded above, not tapering or tapering slightly downwards, very briefly pedicellate, $45-55 \times 6-7 \mu$, wall ca. $1 \mu$ thick, slightly thickened, $2 \cdot 5 \mu$ at the apex. Spores distichous, oblong-clavate, 1-septate, hyaline, $12 \cdot 5-15 \times 2-3 \mu$, upper cell slightly shorter and broader than the lower, broadly rounded above, tapering gradually downwards. Paraphyses slender, filiform, disappearing early. 33545 .

on leaves of Carissa bispinosa (L.) Desf., Mtunzini, near Eshowe. E. M. Laughton,

Under a hand lens this fungus has not a definitely stellate appearance; the strands forming the epistroma are not very long and are surrounded by the thick, ruptured epidermis, which holds them more or less erect; they are thus recurved rather than spreading, but are distinctly radiating.

197. Microcyclus kentaniensis Doidge nov. spec.

Stromata caulicola, in greges plus minus elongatos usque $5 \mathrm{~mm}$. longos aggregata, superficialia, atra, opaca, tubereulata, 400-750 $\mu$ lata, $200-250 \mu$ alta, pede breve centrali, 
150-200 $\mu$ crassa, innato suffulta, e cellulis $7 \cdot 5-10 \mu$ diam. contexta. Loculi immersi, usque 15 in quoque stromate, $100-125 \mu$ lati, $110-140 \mu$ alti, prominuli. Asci fasciculati , oblongo-clavati, recti v. curvati, stipitati, $60-75 \times 10-12.5 \mu$. Sporae plerumque distichae, oblongae, medio septatae, haud vel vix constrictae, $20-22 \cdot 5 \times 3-4 \mu$.

Hab. in caulibus Asparagi plumosi, Kentani, leg. A. Pegler, 8885.

Stromata caulicolous, in irregular elliptical groups up to $5 \mathrm{~mm}$. long, on yellow-brown, indeterminate spots, superficial, round to irregular in outline, 400-750 $\mu$ diam., 200-250 $\mu$ high, irregularly tuberculate, with dull dark red or black surface in which the ostioles show as pale spots; connected with the hypostroma in the cortical tissues by a short central foot, which ruptures the thick cuticle and expands to form the fertile part of the stroma. Foot $150-200 \mu$ broad, composed of prosenchymatous rows of cells 5-6 $\mu$ broad, which gradually give place to the polygonal parenchyma of the outer layers of the stroma, with cells $7 \cdot 5-10 \mu$ diam. Loculi $6-10$, or up to 15 in each stroma, fairly regularly spaced, each under a tubercular prominence of the stroma, 100-125 $\mu$ broad, 110-140 $\mu$ high, subglobose to ovate, lined with elongated stroma cells 10-13 $\mu$ long, 4-6 $\mu$ broad. Asci borne on a layer of floccose hyphae which line the inner wall of the loculus and converge at the ostiole like periphyses. Ostiole short, broadly truncate-conical. Asci fasciculate, 8-spored, oblong-clavate, straight or curved, rounded above, pedicellate, $60-75 \times 10-12.5 \mu$, with knob-like foot $34 \mu$ long, often bent or curved. Spores distichous, oblong, hyaline, 1 -septate, not constricted at the septum or slightly so, 20-22.5 $\times 3-4 \mu$; cells more or less equal in length or the upper slightly shorter and broader; the lower cell cylindrical, the upper slightly dilated above the septum and tapering to the rounded apex.

on stems of Asparagus plumosus Bkr., Kentani, A. Pegler, 8885.

\section{Erysiphe Brachystegiae Doidge nov. spec.}

Mycelium amphigenum, effusum, persistens, albidum. Conidia ellipsoidea v. cylindracea, $27 \cdot 5-40 \times 11-15 \mu$. Perithecia haud numerosa, sparsa v. subgregaria, globosodepressa, 180-260 $\mu$ diam., cellulis parietis exterioris indistinctis. Appendices 25-40 in quoque perithecio, aequatoriales, ubique hyalinae, simplices, rectae $\mathrm{v}$. flexuosae, plerumque $500-750 \mu$ longae, basim 5- $6 \mu$ latae, crasse tunicatae, sursum versus non vel leniter latiores, ad apicem simplices, rectae v. lenissime incurvatae. Asci ca. $20-25$ in quoque perithecio, ovati $v$. subclavati, antice late rotundati, postice attenuati, $80-100 \times 45-55 \mu$. Sporae plerumque 8 , hyalinae, continuae, ellipsoideae, $25-30 \times 15-17 \cdot 5 \mu$.

Hab. in foliis Brachystegiae Randii, Salisbury, leg. Hopkins, 25946, 29921.

Mycelium amphigenous, effuse, white or yellowish. Conidia ellipsoid to cylindrical, $27 \cdot 5-40 \mu$ long, $11-15 \mu$ broad. Perithecia not numerous, scattered or in small groups, 180-260 $\mu$ diam., slightly flattened-globose. Outer cells of perithecial wall small, obscure. Appendages numerous, 25-40, forming a white ring round the perithecia, equatorial, hyaline throughout, radiating, simple, straight or flexuous, mostly 500-750 $\mu$ long; thick-walled at the base and $5-6 \mu$ broad, straight at the tip, sometimes slightly dilated, occasionally slightly incurved, not typically uncinate. Asci ca. 20-25 in each perithecium, ovate or subclavate, broadly rounded above, tapering more or less below to a short foot, $80-100 \mu$ long, 45-55 $\mu$ broad, 8 -spored. Spores usually 8 , seldom fewer, ellipsoid, hyaline, continuous $25-30 \mu$ long, $15-17 \cdot 5 \mu$ broad.

on leaves of Brachystegia Randii Bak. f., Salisbury, Hopkins 1647, 25946, 26621.

This fungus was listed by Hopkins as Uncinula sp. in his "Descriptive List of Plant Diseases in S. Rhodesia " (Mem. Dept. Agric. S. Rhodesia No. 2, 1939, p. 7). The appendices are oceasionally slightly incurved at the tips, but none were seen which were typically uncinate. The material is unfortunately scanty. 
199. Erysiphe communis (Wallr.) Link.

in Willd. Sp. Plant. 6 (1824) p. 105, pro pgrte.

Blumer, Erysiph. Mittel-europas (1933) p. 177.

as Erysiphe Polygoni DC. in Doidge, Trans. Roy Soc. S. Afric. 5 (1915), p. 241.

Mycelium and conidial form variable. Conidia usually single, rarely in chains, 26-40 $\times 15-17 \cdot 5 \mu$. Perithecia scattered or more or less grouped, flattened-globose, $75-130 \mu$ diam.; cells of perithecial wall irregularly angular, $10-25 \mu$ diam. Appendages basal, hyaline or brown, usually myceloid, tortuous, 1-5 times as long as the diameter of the perithecium. Asci 3-10,50-70 × 30-50 $\mu, 3-6$-spored. Spores hyaline, ellipsoid, continuous, $18-25 \times 10-15 \mu$.

on leaves of Triumfetta Sonderii Ficalho and Hiern., Sunnyside, Pretoria, Doidge' 2291 and $v . d$. Byl, 8880 .

200. Erysiphe Jatrophae Doidge nov. spec.

Mycelium amphigenum, plagulas plus minus rotundatas albidas efficiente vel totam folii paginam obtegente. Conidia ellipsoidea, 30-40 $\times 15-20 \mu$. Perithecia sparsa v. laxe gregaria, globosa, 90-105 $\mu$ diam., cellulis parietis exterioris 15-20 $\mu$ diam. Appendices breves, plerumque dimidium perithecii diametrum subaequantes, sat numerosae hyalinae, tenues, tortuosae, simplices. Asci plerumque 3, rarius 2, rarissime 4 in quoque perithecio, ovati, sessiles v. vix pedicellati, 35-57.5 $\times 38-45 \mu$. Sporae 4-6, ellipsoideae, hyalinae, continuae, $17 \cdot 5-22 \cdot 5 \times 9-12 \cdot 5 \mu$.

Hab. in foliis Jatrophae Zeyheri, Pietersburg, leg. Thomsen, 1286.

Amphigenous, forming more or less round white patches, or covering the whole leaf surface. Conidia ellipsoid, 30-40 $\mu$ long, 15-20 $\mu$ broad. Perithecia on both sides of the leaf, scattered or loosely grouped, globose, 90-105 $\mu$ diam. Cells of perithecial wall irregularly angular, 15-20 $\mu$ diam, Appendages short, length not more than half the diameter of the perithecium, fairly numerous, hyaline, delicate, tortuous and mycelium-like. Asci mostly 3 , sometimes 2 , very rarely 4 in each perithecium, ovate, sessile or very briefly pedicellate, 35-57.5 $\times 38-45 \mu, 4-6$ spored. Spores ellipsoid, hyaline, continuous, $17 \cdot 5-$ $22 \cdot 5 \mu$ long, $9-12 \cdot 5 \mu$ broad.

on leaves of Jatropha Zeyheri Sond., Pietersburg, Thomsen, 1286, Type.

Jatropha natalensis Müll. Arg. Ehlanzeni, Doidge, 8248 (Oidium only).

Jatropha Woodii O. Ktze., Ladysmith, Pole Evans, 2030. (Oidium only).

Acalypha angustata Sond., Garstfontein, Pretoria Distr., Erasmus, 1266.

Sub Erysiphe Polygoni DC. in Doidge, Trans. Roy. Soc. S. Afric. 5 (1915), p. 241. This species belongs to the Erysiphe Polygoni group and is near Erysiphe Urticne (Wallr.) Klotzsch.

201. Erysiphe nitida (Wallr.) Rabenh.

Deutschl. Krypt. Fl. 1 (1844), p. 231.

Blumer, Erysiph. Mittel Europas (1933), p. 229.

Erysiphe Polygoni DC. emend. Salmon, Mem. Torrey Bot. Club 9 (1900) p. 174, pro parte.

Amphigenous and caulicolous, often causing discolouration of the stem tissues under the mycelium. Mycelium well developed, more or less persistent. Conidia ellipsoid, 25-37 $\mu$ long, 14-20 $\mu$ broad. Perithecia scattered or in groups, globose or flattened globose, 75-110 $\mu$ diam. ; cells of the perithecial wall distinct, polygonal, $10-25 \mu$ diam. Appendages not very numerous, 5 to 30 to each perithecium, usually tortuous, mycelium-like, 1 to 5 times as long 
as the diameter of the perithecium, only a few reaching the maximum length, septate, arising from the base of the perithecium, light brown, rather thick-walled at the base and ca. $5 \mu$ broad, becoming paler and thinner walled upwards ; occasionally irregularly branched, especially near the tip. Asci usually 2-6 in each perithecium, seldom as many as 8 and exceptionally only 1 , ovate, sessile or briefly pedicellate, $50-70 \mu$ long, $30-45 \mu$ broad. Spores 3-5, seldom 2, in each ascus, ellipsoid, hyaline, continuous, 18-25 × 10-15 $\mu$.

on Delphinium Ajacis Linn., Johannesburg, Sieling, 14123; Areadia, Pretoria, Bottomley, 23624 ; Imvani, Cape, Bisset, 26598.

Delphinium cultorum Voss, New England Rail, Cape, Laurence, 25928 ; Salisbury, Hopkins, 25947 ; Durban, McClean, 24897 ; White River, Wager, 27694 ; Brook1y n, Pretoria, Doidge, 28510, 28957 ; Pietermaritzburg, Schmulz, 30120.

on Knowltonia glabricarpellata Huth, Knysna, Bottomley, 32261. (Oidium only).

202. Erysiphe umbelliferarum de Bary.

Beitr. z. Morph. u. Phys, Pilze 1 (1870) p. 50.

Blumer, Erysiph. Mittel-Europas (1933), p. 195.

Mycelium and conidia well developed, amphigenous and caulicolous. Hyphae much branched, with more or less definitely lobed haustoria. Conidia abstricted singly, rarely in short chains, small, cylindrical, $30-42 \mu$ long, $12-18 \mu$ broad. Perithecia much flattened, 90-115 $\mu$ diam. ; cells of perithecial wall small, often obscure. Appendages usually numerous, short, once to twice as long as the diameter of the perithecium, brown, often irregularly bent and usually once, or several times, irregularly branched. Asci 3-8, seldom up to 19 in each perithecium, ovate to subglobose, very briefly pedicellate, $55-70 \times 30-45 \mu$, $3-5$, seldom 6-spored. Spores ellipsoid, hyaline, continuous, $20-28 \times 10-15 \mu$.

on Trachymene caerulea Graham, leaves and stems, Utrecht, v. d. Spuy, 30929.

The fungus on Trachymene has usually about 5 asci in each perithecium, and $4-5$ spores in each ascus. The appendages are not very numerous and are rather sparingly branched ; otherwise it agrees closely with the description given by Blumer (l.c.). He mentions a wide range of hosts belonging to the Umbelliferae, but Trachymene is not included.

\section{Phyllactinia Acaciae Syd.}

Ann. Mye. 33 (1935), p. 233.

Hypophyllous; mycelium effuse, fairly well developed, more or less persistent, formed of hyphae 3-5 $\mu$ thick. Conidia cylindrical, 45-60 $\mu$ long, obtusely rounded at both ends, often with lateral walls somewhat concave, and thus $10-12 \cdot 5 \mu$ broad at the ends, 6-9 $\mu$ broad in the centre. (According to Sydow l.c., the conidia are 50-70 $\times .12-16 \mu$, but none of those examined exceeded the measurements given above.) Perithecia scattered, not numerous, $120-210 \mu$ diam.; cells of perithecial wall rather obscure, ca. 10-12.5 $\mu$ diam. Appendages 6-12, hyaline throughout, rigid, simple, ca. 90-150 $\mu$ long: bulbous base $25-35 \mu$ diameter; above the swollen base, appendages are $7 \cdot 5-10 \mu$ thick and thickwalled, tapering to $2 \cdot 5-4 \mu$ at the tip where the wall is thinner : near the base the wall is ca. $2 \cdot 5 \mu$ thick and the lumen almost obliterated, but the thickness is uneven. Asci ca. 5-10 in each perithecium, ovate, briefly pedicellate, $45-60 \times 20-30 \mu, 2-3$-spored. Spores hyaline, ellipsoid, continuous, ca. $22-30 \times 12-14 \mu$.

on Acacin robusta Burch., on leaves, Klapperkop, near Pretoria, Mogg, 23428 (Type collection).

Unfortunately there are very few perithecia on the type collection, and these are barely mature. Fungi belonging to the Erysiphaceae form perithecia comparatively rarely under South African conditions, and they are seldom found on cultivated plants. 
204. Phyllactinia Combreti Doidge nov. spec.

sub Phyllactinia corylea (Pers.) Karst., in Doidge, Trans. Roy. Soc. S. Africa 5 (1915), p. 242.

Mycelium hypophyllum, persistente, primitus plagulas rotundatas v. irregulares albidas efficiente, deinde effusum, magnam folii partem obtegente. Conidia oblongo-ellipsoidea, rarius subelavata, plerumque utrinque leniter attenuata, $62 \cdot 5-80 \times 17 \cdot 5-22 \cdot 5 \mu$. Perithecia sat numerosa, sparsa, globoso-depressa, 275-400 $\mu$ diam.; cellulis parietis exterioris obscuris. Appendices 15-20 in quoque perithecio, ubique hyalinae, 220-450 $\mu$ longae, parte basali vesiculoso-inflatae, 35-50 $\mu$ diam., supra basim bulbosum 15-20 $\mu$ latae, crasse tunicatae, sursum versus leniter attenuatae ad apicem tenuiter tunicatae, $8-10 \mu$ latae. Asci numerosi, ca. 40-50 in quoque perithecio, oblongi v. ovati, antice late rotundati, postice breviter pedicellati, $80-95 \times 27 \cdot 5-37 \cdot 5 \mu$, crasse tunicati, 2-3 spori. Sporae ellipsoideae, hyalinae, continuae, $35-40 \times 17 \cdot 5-25 \mu$.

Hab. in foliis Combreti Zeyheri, Pretoria, leg. Doidge, 1506.

Hypophyllous; mycelium fairly well developed, at first forming round to irregular, white or yellowish blotches, later effuse, covering a great part of the leaf surface; more or less persistent. Conidia oblong-ellipsoid, rarely subclavate, usually tapering slightly to rounded ends, $62 \cdot 5-80 \times 17 \cdot 5-22 \cdot 5 \mu$. Perithecia fairly numerous, scattered, flattenedglobose, 275-400 $\mu$ diam. : cells of perithecial wall obscure. Appendages 15-20 to each perithecium, $220-450 \mu$ long, hyaline throughout; bulbous base $35-50 \mu$ diam. ; above the swollen base, $15-20 \mu$ thick and thick-walled, wall ca. $4 \mu$ thick ; rapidly becoming thinwalled above and tapering very slightly to the tip, which is delicate, easily crushed and 8-10 $\mu$ thick. Asci numerous, ca. 40-50 in each perithecium, oblong or ovate, 80-95 $\times$ $27 \cdot 5-37 \cdot 5 \mu$, contracted rather suddenly below into a foot which is straight and peg-like or is bent ; foot up to $20 \mu \mathrm{long}$; asci thick-walled, 2-3-spored. Spores ellipsoid, hyaline, continuous, $35-40 \times 17 \cdot 5-25 \mu$. Penicillate cells rather well developed.

on Combretum Zeyheri Sond., on leaves, Sunnyside, Pretoria, Doidge, 1506 (Type), and Pole Evans, 9743 ; Letaba Drift, Doidge, 1806.

\section{Phyllactinia Erythrinae Doidge nov. spec.}

Mycelium hypophyllum, persistente, albidum, saepe densum, totam folii paginam obtegens, interdum tenue, plagulas irregulares efficiens. Conidia clavata, $62 \cdot 5-87 \cdot 5 \times$ $15-2 \overline{2} .5 \mu$, plerumque $75-80 \times 17 \cdot 5 \mu$, antice rotundata, postice ad basim truncatam 7-9 $\mu$ latam attenuata. Perithecia sat numerosa, subgregaria, globosa, 180-240 $\mu$ diam., cellulis parietis exterioris 10-15 $\mu$ diam. Appendices 9-15 in quoque perithecio, rectae, haud septatae, basi vesiculo-inflatae 37-5-45 $\mu$ diam., supra basim bulbosam 10-15 $\mu$ latae, crasse tunicatae, sursum sensim attenuatae ad apicem 4-5 $\mu$ latae tenuiter tunicatae. Asci immaturae.

Hab. in foli.s Erythrinae caffrae, Greytown, leg. Doidge, 15418.

Hypophyllous. Mycelium and oidial stage often well developed, dense, completely covering the under side of the leaf; sometimes thin, arachnoid, and forming only irregular patches. Conidia clavate, $62 \cdot 5-87 \cdot 5 \mu$ long, $15-22 \cdot 5 \mu$ broad in the broadest diameter, which is usually about one-third of the distance from apex to base; rounded at the apex, tapering to the truncate base, which is $7-9 \mu$ broad : most of the conidia are $75-80 \times 17 \cdot 5 \mu$. Perithecia often numerous, closely and fairly evenly distributed in the mycelium or in small groups, but not closely crowded, globose, $180-240 \mu$ diam. ; cells of the perithecial wall rather obscure, ea. 10-15 $\mu$ diam. Appendages 9-15 to each perithecium, simple, straight, non-septate, longer than the diameter of the perithecium, 350-450 $\mu$ long; basal swelling $37 \cdot 5-45 \mu$ diam. ; appendages $10-15 \mu$ thick just above the bulbous base and thick-walled, tapering gradually and becoming thinner-walled towards the tip, which is $4-5 \mu$ broad. 
Penicillate cells numerous, well developed. Asci quite immature in all the perithecia examined.

on Erythrina caffra Thunb., on leaves, Greytown, Doidge, 15418, Type ; Nelspruit, Wager, 23398.

Oidium only; Durban, 25895; Harden Heights, Pole Evans, 1394; Nelspruit, Liebenberg, 25991.

\section{Phyllactinia Evansii Doidge nov. spec.}

Mycelium hypophyllum, tenue, effusum, subpersistens. Conidia oblonga, antice late rotundata, basi rotundata $v$. truncata, 45-55 $\times 10-15 \mu$. Perithecia sparsa, globosodepressa, $180-220 \mu$ diam., cellulis parietis exterioris subobseuris, angulato-rotundatis, 7-10 $\mu$ diam. Appendices 10-15 in quoque perithecio, ubique hyalinae, rigidae, $150-200 \mu$ longae, basi vesiculoso inflatae $25-35 \mu$ diam.; supra basim bulbosam 7-10 $\mu$ latae, crasse tunicatae, ad apicem tenuiter tunicatam ca. $4 \mu$ latam sensim attenuatae; plerumque simplices, interdum furcatae. Asci numerosae, usque 40 in quoque perithecio, ovati, raro oblongi, breviter pedicellati, 55-70 $\times 22-35 \mu$, plerumque 2 - rarius 3 -sporae. Sporae ellipsoideae, hyalinae, continuae, $20-35 \times 10-17.5$ plerumque $30-35 \times 15-17.5 \mu$.

Hab. in foliis Burkeae africanae, Wonderboom, prope Pretoria, leg. Pole Evans, 9758.

Hypophyllous. Mycelium rather thin, effuse, more or less persistent. Conidia oblong. broadly rounded above, rounded or truncate at the base, 45-55 $\times 10-15 \mu$. Perithecia scattered, flattened-globose, $180-220 \mu$ diam.; structure of the perithecial wall rather obscure, formed of rounded-angular cells 7-10 $\mu$ diam. Appendages 10-15 to each perithecium, hyaline throughout, rigid, 150-200 $\mu$ long; bulbous base $25-35 \mu$ diam.; above the swollen base, usually simple, $7-10 \mu$ thick, tapering upwards to about $4 \mu$ at the rounded apex; wall up to $2.5 \mu$ thick, or the lumen obliterated in places, wall getting gradually thinner upwards; occasionally forked just above the bulbous base, branches nearly equal, or one much shorter than the other. Asci numerous, up to 40 in each perithecium, ovoid, rarely oblong, briefly pedicellate, 55-70 × 22-35 $\mu$, 2-spored, rarely 3-spored. Spores ellipsoid, hyaline, continuous, $30-35 \times 10-17 \cdot 5 \mu$, mostly $30-35 \times 15-17 \cdot 5 \mu$, the smaller spores in the 3 -spored asci.

on Burkea africana Hook., on leaves, Wonderboom, Pretoria district, Pole Evans, 9758.

\section{Phyllactinia rhoina Doidge nov. spec.}

Mycelium hypophyllum, tenuissimum, effusum. Perithecia sparsa, globoso-depressa, 180-220 $\mu$ diam., cellulis parietis exterioris obscuris. Appendices 6-9 in quoque perithecio, 200-300 $\mu$ longae, basi vesiculoso-inflatae, 45-50 $\mu$ diam., supra basim bulbosam 10-11 $\mu$ latae, crasse tunicatae, sursum versus leniter attenuatae ad apicem fragilem ca. $6 \mu$ latam. Asci numerosi ca. $20-30$ in quoque perithecio, ovati v. oblongi, apice late rotundati, infra pedicellati, 2 -spori rarius 3 -spori. Sporae vix maturae, hyalinae, continuae, ellipsoideae, $30-37 \cdot 5 \times 17 \cdot 5-21 \mu$.

Hab. in foliis Rhois pyroides var. transvaalensis, Garstfontein prope Pretoria, leg. Pienaar, 6662.

Hypophyllous. Mycelium not conspicuous, conidia not seen. Perithecia scattered, flattened-globose, $180-220 \mu$ diam.; cells of the perithecial wall obscure. Appendages 6-9 to each perithecium, $200-300 \mu$ long or possibly longer, as the apices of those examined were usually broken; basal swelling 45-50 $\mu$ diam. ; above the bulbous base 10-11 $\mu$ thick, with wall $2.5 \mu$ thick becoming thinner-walled above and tapering very slightly to an apex $6 \mu$ broad. Asci numerous, ca. 20-30 in each perithecium, ovate or oblong, broadly rounded above, $60-75 \times 25-32 \cdot 5 \mu$, contracted suddenly below into a stalk which is straight or bent 
and 10-25 $\mu$ long; asci 2 -spored, rarely 3 -spored. Spores barely mature, hyaline, ellipsoid, continuous, $30-37 \cdot 5 \times 17 \cdot 5-21 \mu$. Penicillate cells fairly well developed.

on Rhus pyroides Burch, var. transvaalensis Schon., on leaves, Garstfontein, Pretoria district, Pienaar, 6662, Type and 1533; Brits, Moore, 23235.

Rhus discolour E. Mey., Grootfontein, nr. Harrismith, $v$. d. Byl, 2317.

\section{Phyllactinia Sphenostylidis Doidge nov. spec.}

Mycelium hypophyllum, persistens, albidum, effusum. Conidia clavata, apice rotundata, infra attenuata ad basim truncatam, 57.5-80 $\times 20-25 \mu$, plerumque $50-52 \cdot 5 \times$ $20-22 \cdot 5 \mu$. Perithecia sparsa, globoso-depressa, 180-230 $\mu$ diam., cellulis parietis exterioris 10-15 $\mu$ latis. Appendices 5-9 in quoque perithecio, simplices, ubique hyalinae, rigidae, 175-235 $\mu$ longae, basi vesiculoso-inflatae, $35-45 \mu$ diam. ; supra basim bulbosam $10-12 \cdot 5 \mu$ latae, ad apicem $4 \mu$ latam sensim attenuatae. Asci immaturae.

Hab. in foliis Sphenostylidis angustifliae, Groenkloof, prope Pretoria, leg. Bottomley, 17024.

Hypophyllous. Mycelium and conidial stage usually well developed, forming dense, dirty white or yellowish patches, or covering the whole of the under surface of the leaf. Conidia clavate, rounded above, 50-80 $\mu$ long, 20-25 $\mu$ broad at the broadest diameter, which is about one-third of the distance from apex to base, tapering downwards to the truncate base, which is $7 \cdot 5-10 \mu$ broad ; the majority of the conidia are 50-52.5 $\times 20-22 \cdot 5 \mu$. Perithecia scattered, 180-230 $\mu$ diam.; cells of the perithecial wall obscure, $10-15 \mu$ diam. Appendages 5-9 on each perithecium, simple, hyaline throughout, rigid, 175-235 $\mu$ long : swollen base $35-45 \mu$ diam.; above the basal swelling, appendages are 10-12.5 $\mu$ thick with wall ca. $1 \cdot 5 \mu$ thick, tapering gradually upwards and becoming thinner-walled towards' the tip, which is ca. $4 \mu$ thick. Asci quite immature in numerous perithecia examined. Penicillate cells numerous, well developed.

on Sphenostylis angustifolia Sond., on leaves, Groenkloof, Pretoria, Bottomley, 17024 Type ; Sunnyside, Protoria, Pole Evans, 1413, 1510, 6693; Garstfontein, Pretoria district, Pienaar, 2252 ; Waterkloof, Wager. 23357 ; Donkerpoort, Doidge and Bottomley, 29730.

This fungus occurs commonly in the neighbourhood of Pretoria ; abundant material has been collected and examined from late summer to early spring, but no mature asci have been found.

209. Uncinula aspera Doidge.

Trans. Roy. Soc. S. Africa 5 (1915), p. 240.

Epiphyllous. Mycelium thin, arachnoid, whitish, effuse, evanescent or sub-persistent. Perithecia scattered or gregarious, flattened-globose, $90-105 \mu$ diam., with wall composed of rather distinet, irregularly angular cells, $12-17 \cdot 5 \mu$ diam. Appendages equatorial, 15-30 to each perithecium, straight or more or less flexuous, hyaline, simple, aseptate, equal in length to the diameter of the perithecium or exceeding it, 125-165 $\mu$ long ; $5-6 \mu$ thick at the base, becoming gradually broader upward to a thickness of $9 \mu$ below the tip, then tapering to the apex; tips closely uncinate or somewhat spiral; wall ca. $1 \cdot 5 \mu$ thick near the base, becoming gradually thinner upwards, ca. $0.5 \mu$ thick at the apex, roughened externally, especially in the lower half, with small, scattered, irregular protuberances. Asci 4-6 in each perithecium, ovate or subglobose, sessile or very briefly pedicellate, $51-57$ $\times 45-48 \mu, 4-6$-spored. Spores oblong, hyaline, continuous, 18-21 $\times 13-14 \mu$.

on Ficus Petersii Warb., on leaves, Wonderboom, Burtt Davy, 1838. 
210. Uncinula combreticola Doidge nov, spec.

Mycelium amphigenum plerumque epiphyllum, persistens, effusum. Conidia oblonga, utrinque truncata $\mathrm{v}$. sub-rotundata, $30-37.5 \times 14-15 \mu$. Perithecia dense congesta v. discreta, globoso-depressa, 100-140 $\mu$ diam., plerumque ca. $125 \mu$ diam ; csllulis parietis exterioris polygonalibus, $10-12 \mu$ latis. Appendices equatoriales, numerosae, 50-75 in quoque perithecio, $90-140 \mu$ longae, perithecii diametrum subaequantes, hyalinae, simplices, tenue tunicatae, basi 4-5 $\mu$ crassae, sursum leniter dilatatae usque $7 \cdot 5-9 \mu$, rarius $10 \mu$, apice laxe uncinatae v. helicoideae. Asci 5-8 in quoque perithecio, immaturi.

Hab. in foliis Combreti Zeyheri, Nelspruit, leg. Doidge, 22377.

Mycelium amphigenous, but mostly epiphyllous, at first forming rather poorly defined' irregularly circular, scattered spots, on the upper side becoming confluent and covering the greater part of the leaf surface. Mycelium dirty white or yellowish, dense, persistent. Conidia oblong, truncate or somewhat rounded at both ends, 30-37.5 $\times 14-15 \mu$. Perithecia closely crowded in small or large patches, less frequently scattered, globose, flattened, $100-140 \mu$ diam., mostly ca. $125 \mu$; perithecial wall composed of polygonal cells $10-12 \mu$ broad. Appendages equatorial, $50-75$ in number, on an average equalling in length the diameter of the perithecium, $90-140 \mu$ long, hyaline, simple, thin-walled throughout, smooth, occasionally slightly rough in places, not septate; $4-5 \mu$ thick at the base, broadening upwards to $7 \cdot 5-9 \mu$, rarely $10 \mu$, just below the tip and then tapering slightly to the apex ; tips loosely uncinate or loosely spiral. Immature appendages are often distended abruptly below the tip, which is often hastate and straight, later becoming uncinate. Asci 5-8 in each perithecium, immature.

on Combretum Zeyheri Sond., on leaves, Nelspruit, Doidge, 22377, Type ; Ledzee, Doidge, 1793.

\section{Uncinula Eylesii Doidge nov. spec.}

Mycelium amphigenum et petiolicolum, persistens, effusum. Conidia ellipsoidea, 14-30 $\times 10-14 \mu$, plerumque $20-22 \cdot 5 \times 10 \mu$. Perithecia sparsa v. subgregaria, clo bosodepressa, 90-105 $\mu$ diam., cellulis pariete exterioris polygonalibus, 10-15 $\mu$ latis. Appendices 24-26 in quoque perithecio, 80-125 $\mu$ longae, perithecii diametrum subaequantes, simplices, leves, basi brunnea 5-6 $\mu$ latae ad apicem hyalinem 3-4 $\mu$ crassam sensim attenuatae ; apice primitus rectae deinde laxe uncinatae. Asci 5-7 in quoque perithecio, ovati, breviter pedicellati, $35-42.5 \times 20-22 \mu$ (immaturi).

Hab. in foliis Acalyphae ciliatae, Salisbury, leg. Eyles, 13992.

Mycelium amphigenous and petiolicolous, rather densely arachnoid, persistent, at first forming more or less round, poorly defined spots and finally covering the greater part of the leaf surface. Conidia ellipsoid, 14-30 × 10-14 $\mu$, mostly 20-22.5 $\times 10 \mu$. Perithecia scattered or rather loosely grouped, often near the veins of the leaf, flattened-globose, 90$105 \mu$ diam. Appendages 24-36 on each perithecium, usually equalling in length the diameter of the perithecium or somewhat longer, rarely shorter, $80-125 \mu$ long ; $5-6 \mu$ thick at the base, which is golden brown, becoming gradually paler upwards and tapering slightly to the hyaline, rounded apex, which is $3-4 \mu$ thick ; tips at first straight, then very loosely uncinate, forming one complete turn or a half turn, $12 \cdot 5-15 \mu$ across ; simple, smooth, non-septate, wall ca. $1 \mu$ thick throughout or slightly thicker at the base. Asci 5-7 in each perithecium, ovate, briefly pedicellate, $35-42 \cdot 5 \times 20-22 \mu$, immature.

on leaves of Acalypha ciliata Forsk., on leaves, Salisbury, Eyles 2071, 13992.

\section{Uncinula incrassata Salm.}

Ann. Myc. 6 (1908), p. 524.

Sacc. Syll. Fung. XXII : 22 ; Gepp, Journ. Linn. Soc. Bot., 40 (1911), p. 242.

Uncinula Pterocarpi Doidge, Trans. Roy. Soc. S. Africa 5 (1915) p. 240, Pl. II. 
Amphigenous; mycelium densely arachnoid, dirty white or yellowish, often covering the greater part of the leaf surface, persistent. Conidia not seen. Perithecia very numerous, in small or large groups, or more or less scattered, at first yellow, sub-globose, then chestnut colour, flattened-globose, $100-140 \mu$ diam. Perithecial wall composed of polygonal cell 10-12 $\mu$ diam. Appendages 60-120 to each perithecium, thickly set over the whole upper half of the perithecium, varying in length, 50-150 $\mu$ long., i.e., some exceeding the diameter of the perithecium, some only half of its diameter and others intermediate in length; the longer appendages are borne round the central zone of the perithecium and the shorter near its apex. Appendages not septate, 4-7 $\mu$ thick, mostly 5-6 $\mu$, rather irregularly thickwalled throughout; even before the perithecium is mature becoming thick-walled right up to the apex; apex usually simply and closely uncinate, rarely sub-helicoid. Asci 8-12 (3-7 fide Salmon in immature perithecia) ovate, $45-50 \times 20-28 \mu$, briefly pedicellate, often curved, 4-spored. Spores ellipsoid, hyaline, 13-18 × 12-13 $\mu$.

on Pterocarpus rotundifolius (Sond.) Druce (=Pt. sericeus Benth.), Duivelskloof, northern Transvaal, Doidge, 1805.

Although the type of Uncinula incrassata has not been available for comparison, there seems to be no doubt, after a more careful study, that $U$. Pterocarpi Doidge is identical with that species; the original specimen was immature. It was said to be on Pt. melliferus Welw., collected on the Zona River, Jihu, Gazaland, by Swymnerton, but it seems probable that the host was wrongly named. Pt. melliferus occurs in Angola, and is not included in the list of flowering plants collected in Gazaland by Swymnerton. Pt. rotundifolius is a closely related species, and it occurs in Gazaland.

213. Uncinula polychaeta (Berk and Curt.) ex Ellis.

Ellis, Journ. Myc. 2 (1886), p. 43.

Salmon, Mem. Torr. Bot. Club 9 (1900), p. 113. Doidge, Trans. Roy. Soc. S. Afric. 5 (1915), p. 240. (For synonymy and further references see Salmon l.c.).

Hypophyllous ; mycelium dense, in irregular, whitish patches, which are often numerous and cover the greater part of the leaf surface, persistent or completely evanescent. Conidiophores slender, hyaline, 4-5-celled, 120-240 $\mu$ long, 6-7.5 $\mu$ thick at the base, tapering somewhat to $5-6 \mu$ at the apex. Conidia clavate or narrow ovate, hyaline, straight or occasionally curved, rounded above, tapering to the truncate base which is $5 \mu$ broad, 35-75 $\mu$ long, mostly 50-55 $\mu$ long, $14-17 \cdot 5 \mu$ broad in the broadest diameter, which is usually about one-third of the length from apex to base. Perithecia more or less closely gregarious on the patches of mycelium, or scattered, $220-400 \mu$ diam. ; cells of the perithecial wall rather obscure, polygonal, $6-10 \mu$ diam. Appendages very numerous, usually about 200, closely crowded and 50-200 $\mu$ long, in length about one-fourth to two-thirds of the diameter of the perithecium, 4-6 $\mu$ thick at the base, hyaline, smooth, simple, aseptate, tapering slightly upwards to the tip, which is $3 \cdot 5-4 \mu$ thick and closely uncimnate; thick-walled, with the lumen more or less completely obliterated. Asci very numerous, 34-66 in each perithecium, cylindrical to oblong, broadly rounded above, $75-95 \times 20-30 \mu$, narrowed rather abruptly below into a stalk 5-20 $\mu$ (mostly 5-10 $\mu$ ) long, which may be straight, but is usually bent near the base, $3-4$-spored. Spores ellipsoid, hyaline, continuous, $25-30$ $\times 12-15 \mu$.

on Celtis Kraussiana Benth., on leaves, Fountains Valley, near Pretoria, van der Byl, 2096, 2202, Pole Evans, 2336, 2361, Bottomley, 34418; Garstfontein, Pretoria district, Pienaar, 1260 ; Zoutpansberg, Burtt Davy, 181.

This seems to be a variable species; the collection from the northern Transvaal (No. 181) has perithecia $220-320 \mu$ diam., agreeing with the measurements given by Salmon (loc. sit). ; in specimens from the Fountains Valley, the perithecia are almost all $300-400 \mu$ diam. The number of spores in the ascus also varies; in the American examples studied by Salmon, 
the asci are almost always 2 -spored, with rarely a rudimentary third spore present; a Chinese specimen differed in having asci which are regularly 3 -spored; in South African material examined, the asci are 3 - or 4 -spored in almost equal numbers.

The conidia are most abundant in material collected during February, March and April ; leaves showing perithecia in all stages of development were collected in May and June.

\section{Meliola Atalayae Doidge nov. spec.}

Plagulae plerumque epiphyllae, atrae, sparsae, plus minus rotundatae, usque $3-5 \mathrm{~mm}$. diam. Mycelium reticulatum, ex hyphis brunneis, opposite ramosis, plerumque undulatis rarius rectiusculis, 7-9 $\mu$ crassis compositum. Hyphopodia capitata, sat numerosa, plerumque alternantia, rarissime opposita, 14-17.5 $\mu$ longa ; cellula inferiore breve cylindracea, 4-5 $\mu$ longa, $7 \cdot 5-9 \mu$ lata ; superiore ovata $\mathrm{v}$. cylindracea, plerumque late rotundata rarius truncata v. subangulata, rarissime sublobata, 10-12 $\mu$ longa, 10-11 $\mu$ lata. Hyphopodia

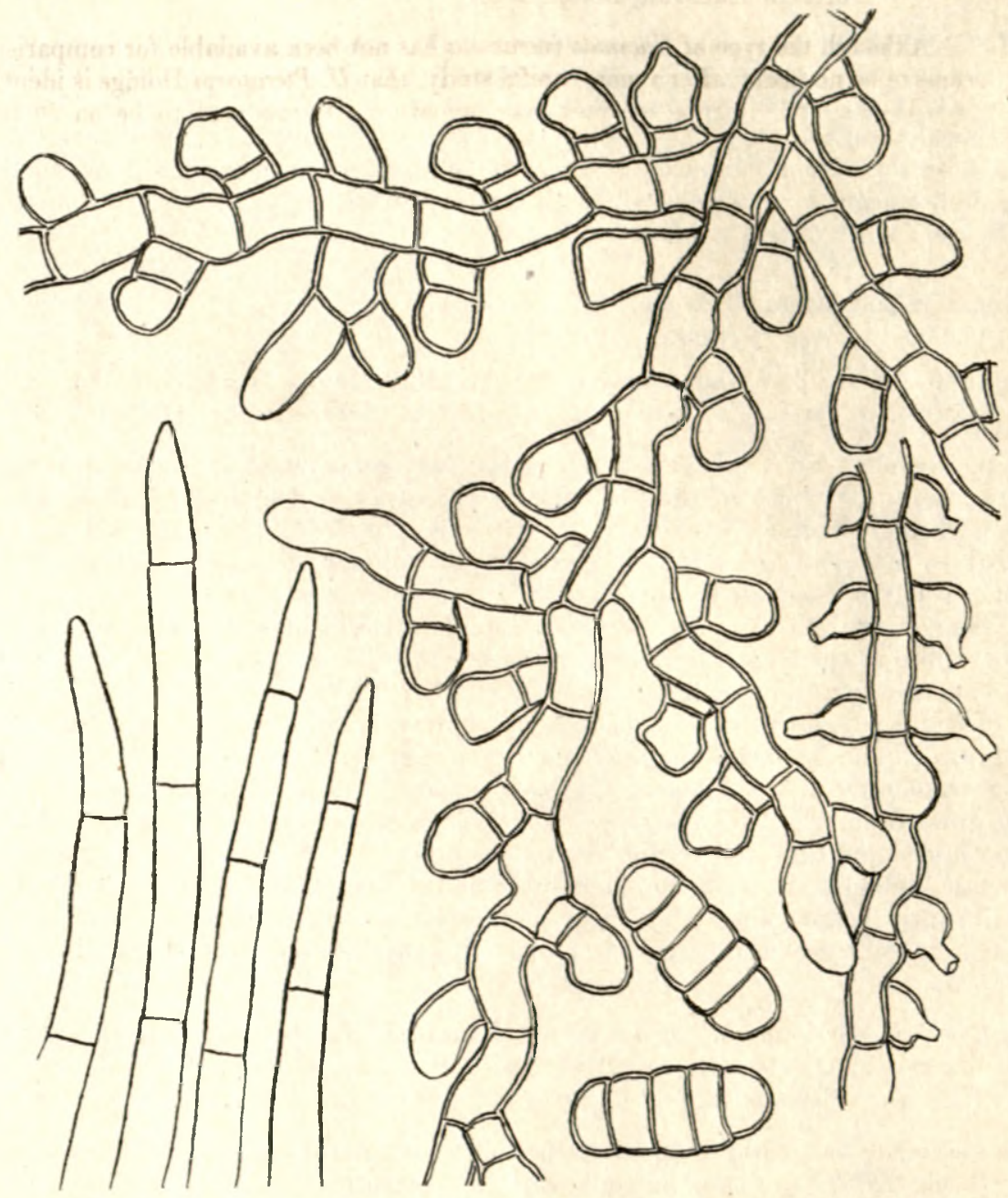

Frg. 1.-Meliola Atalayae, mycelium with capitate and mucronate hyphopodia ; tips of mycelial setae spores. 
mucronata modice numerosa, alternantia, unilateralia v. opposita, haud pallidiore, ampullacea, $12 \cdot 5-17 \cdot 5 \mu$ longa, basi $6-9 \mu$ lata, subito in collum obliquum, curvatum v. interdum rectum, $2 \cdot 5-6 \mu$ longum, $2 \cdot 5-4 \mu$ crassum attenuata. Setae myceliales haud numerosae, praecipue juxta perithecia evolutae, simplices, rectae v. plus minus curvatae, ubique pellucidae, septatae, 180-240 $\mu$ longae, inferne $7-7 \cdot 5 \mu$ crassae, obscure brunneae, apicem versus pallidiores, haud vel vix attenuatae, acutae, rarissime obtusae v. rotundatae. Perithecia globosa, atra, verrucosa, 140-175 $\mu$ diam. Asci 2-spori. Sporae brunneae, 4-septatae, cylindraceae, utrinque rotundatae, leniter constrictae, $30-35 \times 11-14 \mu$.

Hab. in foliis Atalayae natalensis, in sylvis Ngomi, leg. Joubert, 33912.

Colonies predominantly epiphyllous, hypophyllous colonies rare, scattered, dull black, more or less round, up to $3.5 \mathrm{~mm}$. diam.

Mycelium more or less closely reticulate. Hyphae rather thin-walled, snuff-brown shading to deep olive-buff at the tips, 7-9 $\mu$ thick, usually more or less undulating, with short cells 11-15 $\mu$ long; there are some hyphae almost straight, with few hyphopodia and cells up to $35 \mu$ long; branching usually opposite, with branches emerging almost at right angles to the main hyphae. Capitate hyphopodia rather numerous, usually one to each cell of the hypha, mostly alternate, rarely opposite, making a wide angle with the hypha, 14-17.5 $\mu$ long; basal cell short, cylindrical, 4-5 $\mu$ long and 7.5-9 $\mu$ broad; head cell ovate or cylindrical, usually broadly rounded, less frequently truncate or somewhat angular, very rarely sub-lobed, 10-12.5 $\mu$ long, 10-11 $\mu$ broad. Mucronate hyphopodia usually on separate hyphae, but occasionally intermingled with the capitate hyphopodia, alternate, unilateral or opposite, not paler than the hyphae, ampulliform, $12 \cdot 5-17 \cdot 5 \mu$ long; sub-globose to oval at the base, which is 6-9 $\mu$ diam., constricted suddenly above into a neck $2 \cdot 5-6 \mu$ long and $2 \cdot 5-4 \mu$ thick, oblique, curved or occasionally straight. Mycelial setae not numerous, mostly in the neighbourhood of the perithecia, simple, abruptly geniculate at the base and almost straight, or somewhat sinuous, occasionally subfalcate, translucent throughout or sub-opaque near the dark brown base, paler towards the apex; usually 4 -septate, the transverse walls being conspicuous ; $180-240 \mu$ long, $7-7 \cdot 5 \mu$ thick at the base, not tapering or tapering very slightly to the apex, which is $5-7.5 \mu$ thick; apex acute, rarely obtuse or rounded.

Perithecia first formed near the centre of the colony, later scattered, globose, black, carbonaceous, 140-175 $\mu$ diam., surface cells convex to conical. Asci 2-spored, evanescent. Spores cylindrical, 4-septate, slightly constricted at the septa, broadly rounded at both ends, olive-brown, $30-35 \times 11-14 \mu$.

on leaves of Atalaya natalensis R. A. Dyer, Ngomi Forest, Joubert, 33912.

\section{Meliola campylotricha Syd.}

Ann. Myc. 22 (1924) p. 420.

on Cassinopsis tinifolia Harv., Eshowe, E. M. Laughton, 33511.

This is a new host record. Meliola campylotricha was originally described on Apodytes dimidiata E. Mey., collected in the Woodbush by van der Byl (v. d. Byl 1515).

\section{Meliola capnodioides Thuem.}

von Thuemen in Flora 1876, p. 568.

in Plectranthi ciliati E. Mey., foliis vivis in sylvis prope Grahamstown, Promont. bonae spei, Julio 1876. Leg. P. MacOwen, No. 1259.

The portion of the type collection, MacOwan 1259, to be found in the Cryptogamic Herbarium in Pretoria is parasitised, but it is identical with a number of more recent collections on Plectranthus and other Labiates, some of which are in excellent condition. It is obvious that Meliola capnodioides Thuem. is the correct name for the Meliola found on plants belonging to the Labiatae in South Africa. 
For various reasons this specific name has been rejected or overlooked. In 1882, Kalchbrenner (Grev. X : 147) published the following note :-

\section{"Meliola amphitricha Fr.}

In fol. Justiciae anagalloides Nees, Natal, Wood Nos. 241, 22, 57.

In Plectranthi ciliati et Hypsobromo elato ad Somerset East et Grahamstown, leg. MacOwan, Nos. 1259, 1292, 1328."

Several different fungi are quoted by Kalchbrenner under the name Meliola amphitricha; MacOwan No. 1259 is $\boldsymbol{M}$. capnodioides Thuem., No. 1328 is $\boldsymbol{M}$. capensis (Kalchbr. and Cooke) Theiss., and No. 1292 is MacOwaniella congesta (Wint.) Doidge on Carissa bispinosa; in the case of collection 1292, it is possible that $\boldsymbol{M}$. carissae was also present on some of the leaves.

Gaillard [Le Genre Meliola (1892) p. 77] states that according to Cooke $\boldsymbol{M}$. capnodioides Thuem. belongs to $\boldsymbol{M}$. amphitricha and Stevens [Ann. Myc. 26 (1928) p. 289] quotes $\boldsymbol{M}$. capnodioides as a synonyn for $\boldsymbol{M}$. amphitricha Fr., a specific name which, as Arnaud has shown [Les Asterinées (1918) p. 228] must be rejected. Stevens includes a South African fungus on Plectranthus (No. 11576) under Meliola Psychotriae Earle, which was originally described on Psychotria (Rubiaceae) from Porto Rico; he also includes in this species a number of fungi on Acanthaceae.

In the account of the South African species of the Meliolineae [Doidge and Sydow, Bothalia 2 (1928) p. 459], MacOwan 1259 was listed under $\boldsymbol{M}$. Psychotriae Earle, with the comment that the specimen is labelled $\boldsymbol{M}$. capnodioides and is included by Gaillard under $\boldsymbol{M}$. amphitricha $\mathrm{Fr}$. The original description of $\boldsymbol{M}$. capnodioides was not seen until MacOwan's "Opuscula Botanica" were acquired, in which were included reprints from Flora of von Thuemen's papers on Fungi austro-africani.

M. Psychotriae Earle [Bull. N. York Bot. Gard. 3 (1905) 308] is a very similar species, and a critical study of the Meliolas of this group (Group 9, Stevens l.c., p. 233) occurring on Rubiaceae, Acanthaceae and Labiatae is desirable. In view of the habitual narrow host limitation of the species of Meliola, it is hardly likely that a single species will cover a range of hosts including genera of all three families. Should this prove to be the case, the name $\boldsymbol{M}$. capnodioides Thuem. has priority. In the meantime, the South African collections must be classified as follows :-

\section{Meliola capnodioides Thuem.}

von Thuemen, Flora 1876, p. 568 ; Sacc. Syll. Fung. I : 61.

sub Meliola amphitricha Fr., Kalehbrenner, Grev. X (1882) 147 ; Gaillard Le Genre Meliola (1892) 77 ; Stevens, Ann. Myc. 26 (1928) 289.

sub Meliola microspora Pat. and Gaill. var. africana Doidge, Trans. Roy. Soc. S. Afric. V (1917), 732.

sub Meliola microspora Pat and Gaill., Nel. Ann. Univ. Stell. (1942) 20. on Labiatae :

Plectranthus ciliatus E. Mey., Grahamstown, MacOwan 1259, 20799 ; Inanda, Medley Wood 604, 10350, Kew ; Umzinto Bush, Wager, 32697.

Plectranthus sp., Buccleuch, Doidge, 11576; Inanda, Medley Wood, 10353; Woodbush, Doidge, 1766.

Stachys aethiopica Linn., Xumeni Forest, Morgan and Doidge, 29895.

Stachys sp., Kat River Valley, Moore, 21027 ; Xumeni Forest, Doidge, 33110.

Labiatae undet., Woodbush, Doidge 17768.

The collections on Acanthaceae previously included (Doidge and Sydow, l.c.) under M. Psychotriae Earle are not this species, and are being dealt with by Mr. C. G. Hansford in one of the papers in his series on Tropical Fungi. 
217. Meliola Hippocrateae Doidge nov. spec.

Plagulae epiphyllae tenues, effusae. Mycelium reticulatum, ex hyphis brumneis, opposite ramosis, rectiusculis v. leniter undulatis, $6-7 \mu$, raro usque $9 \mu$ erassis compositum, Hyphopodia capitata sat numerosa, plerumque alternantia v. unilateralia, raro opposita, plerumque paullo antrorsum directa, cellula basali breviter cylindracea, $2 \cdot 5-6 \mu$ longa et 5-7.5 $\mu$ lata, apicali ovata v. cylindracea, 11-14 $\mu$ longa et 8-10 $\mu$ lata. Hyphopodia mucronata opposita $\mathrm{v}$. unilateralia, ampullacea, plus minus curvata v. gibbosa, raro rectiuscula, $15-25 \mu$ longa, e basi 5-7.5 $\mu$ lata subito in collum $7 \cdot 5-15 \mu$ longum et ca. $2 \cdot 5 \mu$ latum, rectum obliquum v. curvatum attenuata. Setae myceliales modice numerosa, praecipue juxta perithecia evolutae, $250-400 \mu$ longae, ad basim 6-7.5 $\mu$ latae, atrobrumneae subopacae, sursum sensim attenuatae ad apicem pellucidem vario modo denticulatae $v$. breviter furcatae dentibus plerumque $2-3,5-7 \cdot 5 \mu$ longis $\mathrm{v}$. bifurcatae ramulis usque $12 \cdot 5 \mu$ longis interdum denticulatis, vel irregulariter denticulatae v. incisae. Perithecia haud numerosa, globosa, atra, verrucosa, $150-170 \mu$ diam. Asci non visi. Sporae oblongae, utrinque rotundatae, 4-septatae, plus minus constrictae, 37.5-45 × 13-15 $\mu$.

Hab. in foliis Hippocrateae Schlechteri, Karkloof prope Maritzburg, leg. Doidge, 14971.

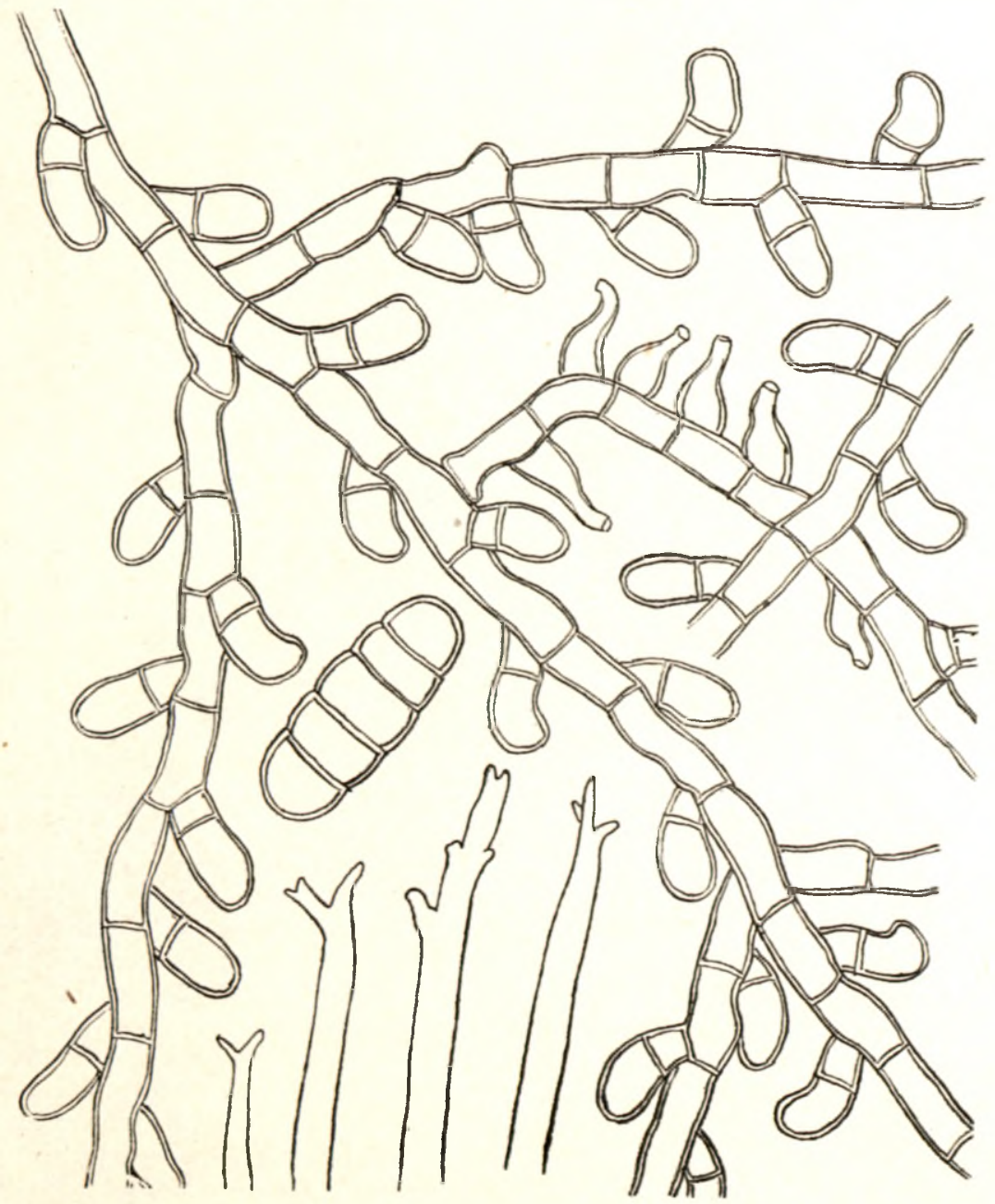

Fra. 2.-Meliola Hippocrateae, mycelium with capitate and mucronate hyphopodia; tips of mycelia setae; spores. 
Colonies epiphyllous, thin, effuse. Mycelium reticulate; hyphae dark olive-buff to snuff-brown, straight to undulating slightly, $6-7 \cdot 5 \mu$ or occasionally up to $9 \mu$ thick ; cells 17.5-25 $\mu$ long; branching usually opposite. Capitate hyphopodia fairly numerous, mostly alternate or unilateral ; often alternate, with one hyphopodium to each cell of the hypha, occasionally opposite, 14-20 $\mu$ long, usually inclined towards the hypha; stipe cell cylindrical, $2 \cdot 5-6 \mu$ long, $5-7 \cdot 5 \mu$ broad ; head cell ovate or occasionally cylindrical, 11-14 $\times 8-10 \mu$. Mucronate hyphopodia interspersed with the capitate hyphopodia or on separate short branches, opposite or unilateral, or opposite a capitate hyphopodium, ampulliform, more or less curved or gibbous, rarely almost straight, not paler than the hyphae, 15-25 $\mu$ long, $5-7 \cdot 5 \mu$ broad at the base, constricted suddenly into a neck which is $7 \cdot 5-15 \mu$ long and $2 \cdot 5 \mu$ thick. Mycelial setae not very numerous, more or less grouped in the neighbourhood of the perithecia, $250-400 \mu$ long, translucent, snuff-brown at the tips, darker, sub-opaque and $6-7.5 \mu$ thick at the base, tapering gradually upwards; tips simple, acute, or 2-3dentate or bifurcate; teeth minute or $5-7 \cdot 5 \mu$ long, more or less symmetrical, or bifurcate, with branches up to $12.5 \mu$ long, one branch sometimes bidentate; or asymmetrically dentate or notched.

Perithecia not numerous, black, globose, carbonaceous, $150-170 \mu$ diam., cells of the perithecial wall slightly convex. Asci not seen. Spores 4-septate, oblong, broadly rounded at both ends, constricted at the septa, 37-5-45 $\times 13-15 \mu$.

on leaves of Hippocratea Schlechteri Loes., Karkloof, nr. Maritzburg, Doidge, 14971.

\section{Meliola Knysnae Doidge nov. spec.}

Plagulae amphigenae, atrae, sparsae, plus minus rotundatae, usque $2.5 \mathrm{~mm}$. diam., vel numerosae et confluendo majores. Mycelium reticulatum, ex hyphis copiose ramosis, brunneis, plus minus undulatis, $7 \cdot 5-9 \mu$ crassis compositum. Hyphopodia capitata alternantia, raro unilateralia, recta v. curvata, $25-37 \cdot 5 \mu$ longa ; cellula basali subcylindracea, 6-12.5 $\mu$ longa, basi $5-6 \mu$, ad septum $6-8 \mu$ lata; apicali quoad formam variabili, $15-20 \mu$ lata, plerumque 2-5-lobata. Hyphopodia mucronata pauca, pallidiora, 20-27.5 $\mu$ longa, e basi $7 \cdot 5-8 \mu$ crassa sensim in collo breve attenuata. Setae myceliales sat numerosae, sparsae, atrae, opacae, simplices, rectae v. plus minus flexuosae v. falcatae, plerumque $400-500 \mu$ longae, inferne 5-9 $\mu$ crassae, sursum leniter attenuatae ad apicem obtusum 2.5-4 $\mu$ latam ; apicem versus saepe leniter dilutiores et interdum plus minus torulosae. Perithecia (vix matura) sparsa, atra, globosa, verrucosa, 120-150 $\mu$ diam. Asci non visi. Sporae 3-septatae, oblongae, utrinque leniter attenuatae, plus minus constrictae, 50-58 $\times 17 \cdot 5-22 \cdot 5 \mu$.

Hab. in foliis Ilicis mitis in sylvis Knysna, leg. Doidge, 17210 a.

Colonies amphigenous, dull black, scattered, more or less circular, up to $2.5 \mathrm{~mm}$. diam., or numerous, becoming confluent and forming larger, irregular blotches. Mycelium reticulate, forming a more or less close network. Hyphae at first pale, fuscous, soon becoming buffy-brown, and older hyphae olive-brown, $7 \cdot 5-9 \mu$ thick, more or less undulating, cells $17 \cdot 5-22 \cdot 5 \mu$ long, hyphae branching rather freely, branches alternate or irregular, usually emerging at an acute angle and tapering slightly at the junction with the main hyphae. Capitate hyphopodia alternate, rarely unilateral, one to each cell of the hypha, or more remote and one to every second cell, straight, curved or abruptly bent, $25-37 \cdot 5 \mu$ long ; basal cell sub-cylindrical, often tapering somewhat to the base, $6-12 \cdot 5 \mu$ long, $6-8 \mu$ thick at the septum, $5-6 \mu$ thick at the base, rarely gibbous; apical cell very variable in form, 15-20 $\mu$ broad, 2-5-lobed; lobes shallow, rounded or truncate, with sinus usually rounded, often broadly so. Mucronate hyphopodia rare, interspersed with the capitate hyphopodia, slightly paler than the hyphae, narrow conical to sub-ampulliform with a short neck, 21-27.5 $\times 7 \cdot 5-8 \mu$. Mycelial setae fairly numerous, scattered, black, opaque except near the apex, simple, straight, abruptly bent almost at right angles or more or less flexuous or falcate, mostly $400-500 \mu$ long, $7 \cdot 5-9 \mu$ thick at the base, tapering gradually to a blunt tip $2 \cdot 5-4 \mu$ thick; sometimes slightly torulose near the apex through nodal swellings near the septa. 


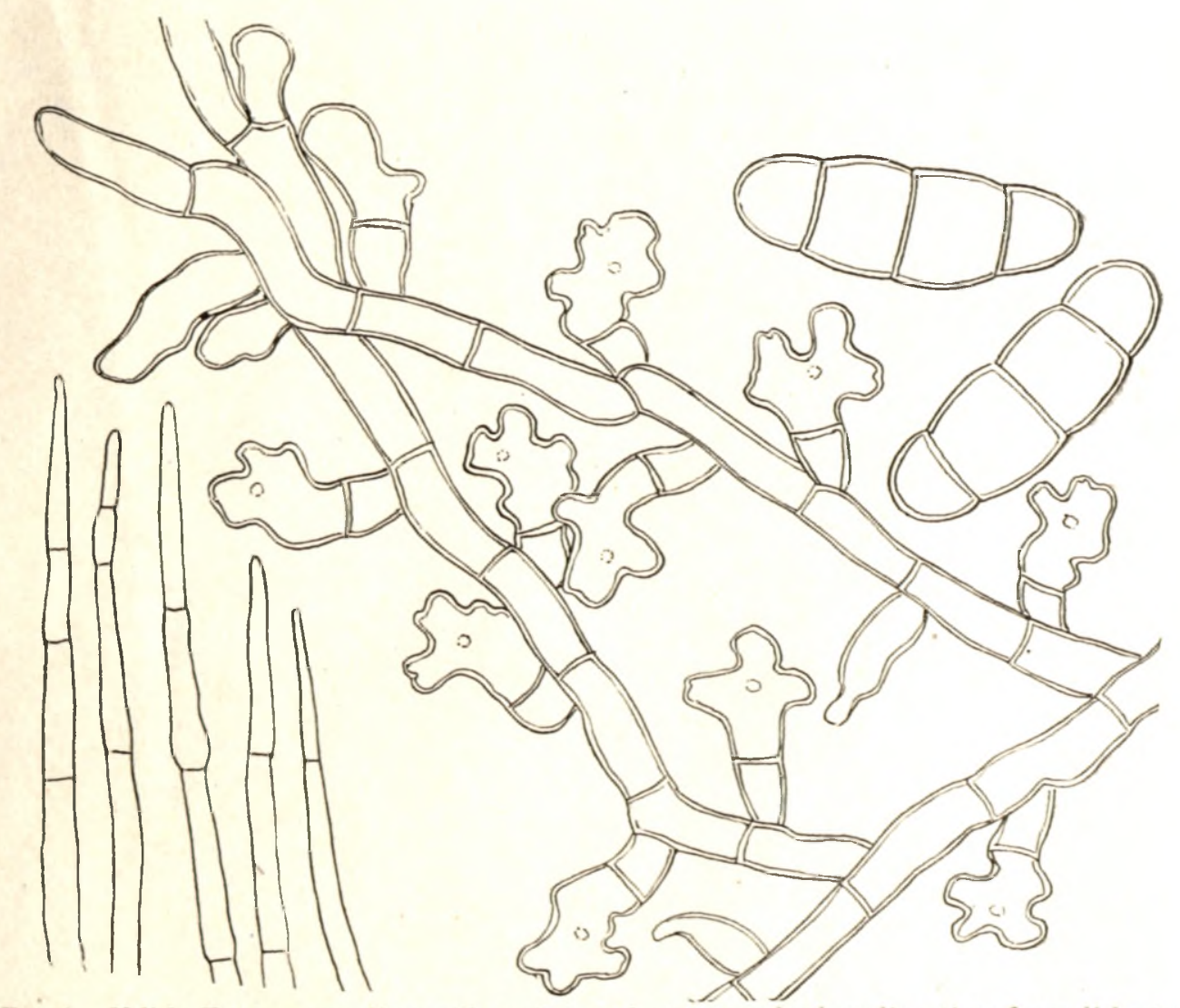

Fig. 4.-Meliola Knysnxe, mycelium with capitate and mucronate hyphopodia ; tips of mycelial setae spores.

Perithecia (not mature) scattered, black, globose, 120-150 $\mu$ diam.; outer wall composed of convex cells. The perithecia would probably be larger when mature. Asci not seen. Spore 3-septate, ellipsoid-oblong, tapering somewhat to broadly rounded ends, slightly constricted at the septa, $50-58 \times 17 \cdot 5-22 \cdot 5 \mu$.

on leaves of Ilex mitis (L.) Radlk., Deepwalls, Knysna, Doidge, 17210 a.

Hennings (Engl. Bot. Jahrb. 17, 1893, p. 523) has described a Meliola on Ilex from Brazil. It has 3-septate spores, 50-65 $\times 18-21 \mu$, approximating in size those of $M$. Knysnae, and has hyphae 10-14 $\mu$ thick, considerably thicker than those of the fungus described above. Neither hyphopodia nor setae are mentioned in the original description, and no specimen was available for comparison.

\section{Meliola Oncinotidis Doidge nov. spec.}

Plagulae epiphyllae, sparsae, aterrimae, plus minus rotundatae, $1-2.5 \mathrm{~mm}$. diam. Mycelium ex hyphis reticulato-ramosis pellucide brunneis, $6-7 \cdot 5 \mu$ crassis, breviter articulatis, cellulis 15-25 $\mu$ longis compositum, ramis oppositis. Hyphopodia capitata numerosa, opposita, alternantia v. unilateralia, recta, rarius leniter curvata, 15-20 $\mu$ longa ; cellula inferiore cylindracea, 3-5 $\mu$ longa, 6-9 $\mu$ lata, superiora ovata, rarius cylindracea, v. paullo irregulari, 12-15 $\mu$ longa, 6-9 $\mu$ lata. Hyphopodia mucronata modice evoluta, opposita v. unilateralia, haud pallidiore, ampullacea, recta v. gibbosa, 15-22.5 $\mu$ longa, basi $6-9 \mu$ ata, subito in collum rectum v. curvatum, 5-9 $\mu$ longum et 2-4 $\mu$ latum attenuata. Setae myceliales numerosae, rectae v. plus minus curvatae, $250-500 \mu$ longae, inferne $7 \cdot 5-9 \mu$ latae, obscure brunneae, subopacae, sursum pallidiores, pellucidae, sensim leniterque 
attenuatae, ad apicem 5-6 $\mu$ latae interdum simplices obtusae, plerumque dentibus 2 mox brevibus $2 \cdot 5-6 \mu$ tantum longis mox elongatis tunc $12 \cdot 5-47 \cdot 5 \mu$ longis praeditae. Perithecia in centro plagularum pauca, aggregata, globosa, atra, 150-220 $\mu$ diam., pariete e cellulis convexis composito. Asci 2-spori, Sporae brunneae, oblongae, 4-septatae, utrinque rotundatae, constrictae, $39-45 \times 14-16 \mu$.

Hab. in foliis Oncinotidis inandensis, Zululand, leg. Gerstner, 33509.

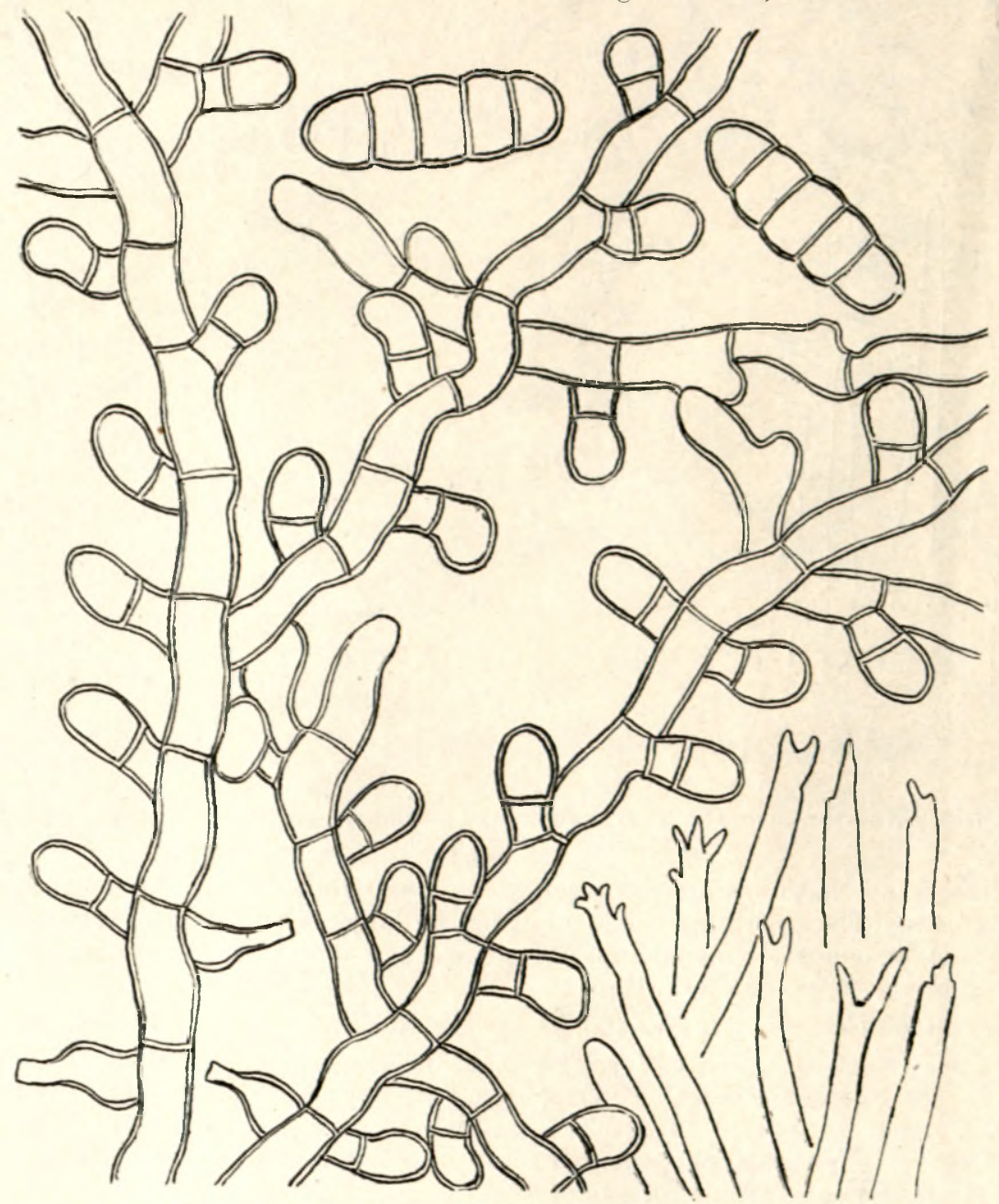

Fro. 5.-Weliola ()ncinotidis, mycelium with capitate and mucronate hyphopodia ; tips of mycelial setne spores.

Colonies epiphyllous, dense, black, round, 1-2.5 mm. diam. Mycelium branching freely, becoming more or less closely reticulate, densely so in the centre of the colony. Hyphae deep olive-buff at the tips, becoming buffy-brown to tawny-olive, undulating, 6-7.5 $\mu$ thick, rather closely septate, cells $15-25 \mu$ long, hyphae often narrowed somewhat near the septa. Branches usually opposite. Capitate hyphopodia numerous, opposite, alternate or unilateral, at right angles to the hypha or inclined towards it at an acute angle, straight, rarely slightly curved, $15-20 \mu$ long ; stipe cell cylindrical, $3-\bar{\jmath} \mu$ long, $6-9 \mu$ broad ; head cell ovate, rarely cylindrical with rounded apex or somewhat irregular, $12-15 \mu$ long, 7.5-10 $\mu$ broad. Mucronate hyphopodia interspersed with capitate hyphopodia, opposite or unilateral, often opposite a capitate hyphopodium, not paler than the hyphae, ampulli- 
form, straight or gibbous, $15-22 \cdot 5 \mu$ long, 6-9 $\mu$ thick at the base, constricted suddenly into a curved or straight neck, $5-9 \mu$ long and $2-4 \mu$ thick. Mycelial setae numerous, straight or abruptly bent at the base, sometimes slightly curved, more or less translucent throughout or sub-opaque near the base, 250-500 $\mu$ long, $7 \cdot 5-9 \mu$ thick and buffy-brown to olive-brown at the base, tapering gradually upwards to 5-6 $\mu$ and becoming paler, deep to dark buff; apex sometimes simple with blunt tip, most frequently bifid with teeth $2 \cdot 5-6 \mu$ long, or with longer tapering branches, $12 \cdot 5-47 \cdot 5 \mu$ long, sometimes minutely and irregularly 3-4-dentate.

Perithecia more or less closely grouped in the centre of the colony, black, globose, carbonaceous, 150-200 $\mu$ diam., surface cells convex. Asci 2-spored, evanescent. Spores snuff-brown, oblong, 4-septate, broadly rounded at both ends, constricted at the septa, $39-45 \times 14-16 \mu$.

on leaves of Oncinotis inandensis Wood and Evans, Zululand, Gerstner 2598, 33509;

Buccleuch nr. Cramond, Natal, Doidge, 9722.

Material is unfortunately very sparse; on No. 9722, the Meliola is associated on the same leaves with Asterina Oncinotidis.

220. Meliola peddieicola Hansford.

Tropical Fungi I, Journ. Limn. Soc., London.

Colonies amphigenous, thin, dull black, effuse and irregular in outline. Mycelium loosely reticulate. Hyphae deep olive-buff at tips, becoming buffy-brown, slightly and

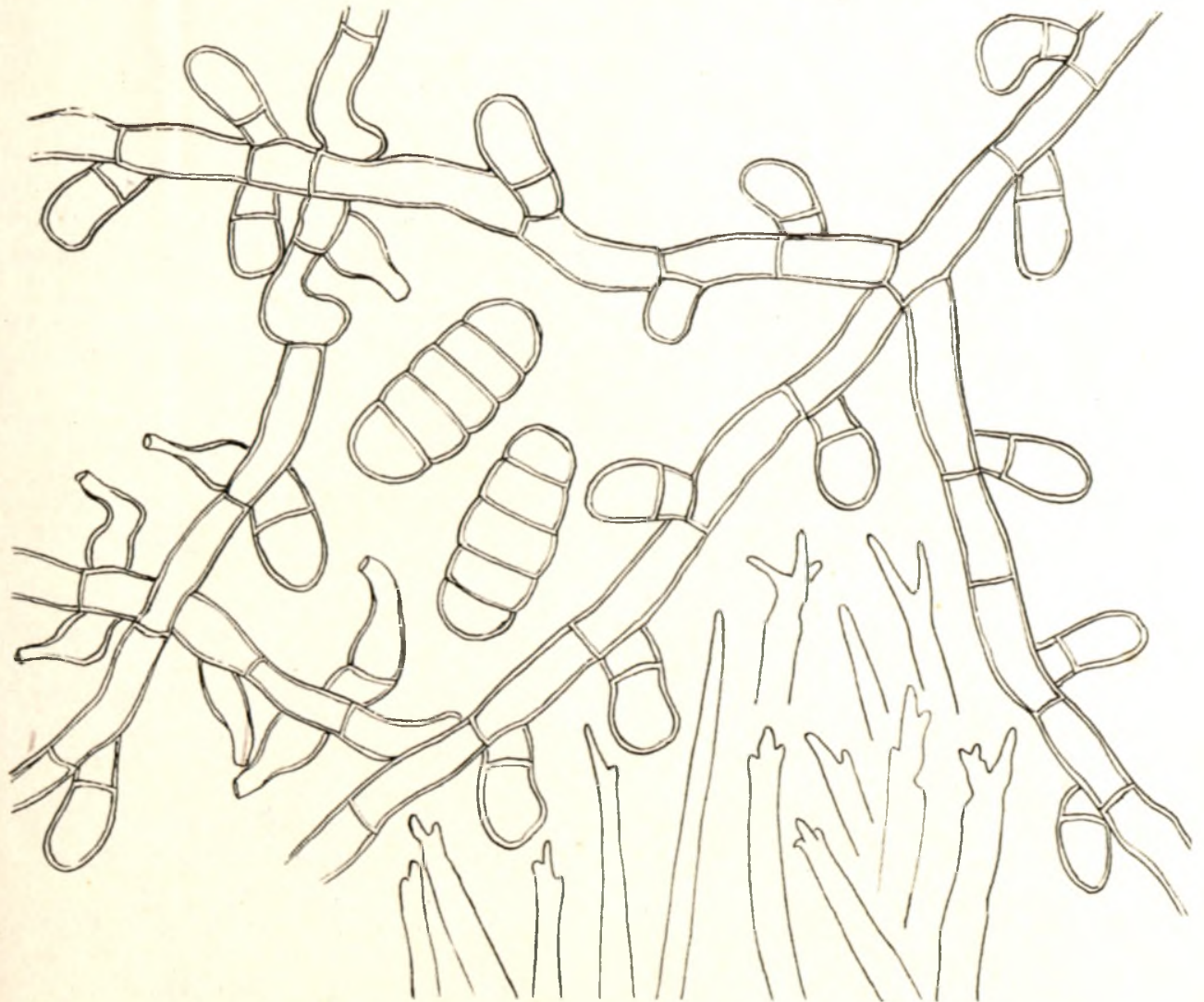

Fig. 6.- Meliola peddieicola, mycelium with capitate and mucronate hyphopodia; tips of myclial setae ; spores. 
irregularly undúlating, 5-7 $\mu$ thick, cells mostly $22 \cdot 5-30 \mu$ long. Capitate hyphopodia alternate, unilateral or occasionally opposite, straight or slightly curved, $17 \cdot 5-22 \cdot 5 \mu$ long ; stipe cell short, cylindrical, ca. $5 \mu$ long and 5-6 $\mu$ thick; head cell 14-17.5 $\mu$ long and 7-10 $\mu$ broad, ovate or cylindrical. Mucronate hyphopodia not numerous, opposite, alternate or scattered, interspersed with the capitate hyphopodia and occasionally opposite to one of them, ampulliform, usually gibbous, rarely straight, $12 \cdot 5-22 \cdot 5 \mu$ long, $6-7 \cdot 5 \mu$ broad at the base, constricted suddenly above into a neck which is $5-6 \mu$ long and $2-2 \cdot 5 \mu$ thick. Mycelial setae not very numerous, mostly grouped round the perithecia, $300-450 \mu$ long, straight but abruptly geniculate at the base, or slightly curved, olive-brown, sub-opaque and 7-9 $\mu$ thick at the base, tapering slightly and becoming somewhat paler towards the apex, which is translucent and buffy-brown; apex simple, acuminate, irregularly notched and toothed with usually $2-3$ minute teeth, or definitely $2-3$-furcate with branches 4-17.5 $\mu$ long; branches often uneven in length and one often bidentate.

Perithecia few, grouped in the centre of the colony, black, globose, carbonaceous, 130-160 $\mu$ diam., surface cells conical. Asci not seen. Spores 4-septate, cylindrical, not tapering or tapering very slightly to broadly rounded ends, slightly constricted at the septa, 35-39 × 12.5-15 $\mu$.

on leaves of Peddiea africana Harv., Woodbush, K. M. Putterill, 32465 b.

\section{Balansia Trachypogonis Doidge nov. spec.}

Pseudosclerotia in gemmis e foliis plerumque tribus constitutis evoluta, semper solitaria, recta v. arcuata, cylindracea compressa, 1-3 $\mathrm{cm}$. longa, basi lata folio obsessa, in media parte 2-3 mm. crassa, apicem versus sensim attenuata, atra, intus albida. Stromata convexa, variae magnitudinis plerumque partem dimidiam inferiorem pseudosclerotiorum sine spatio occupantia, subinde etiam fere ad apicem sclerotiorum producta, tota superficie ob ostiola peritheciorum dense minuteque verrucosa. Perithecia oblongo-lageniformia, immersa, dense stipata, e mutua pressione haud raro plus minus irregularia, 200-350 $\mu$ alta, 70-120 $\mu$ lata, superne subito in ostiola cylindracea v. anguste conica 100-130 $\mu$ longa attenuata; parietibus sub-hyalinis 12-16 $\mu$ crassis separata. Asci longe cylindracei, plerumque recti sed quandoque etiam curvuli, p. sp. $150-200 \mu$ longi, ca. $5 \mu$ lati, postice in stipitem tenuem attenuati, antice rotundati, tenuiter tunicati, ad apicem ca. $5 \mu$ incrassati, 6-8-spori. Sporae tenuiter filiformes, longitudinem ascorum fere aequantes, 1.25$2 \cdot 5 \mu$ crassae, hyalinae, pluriseptatae, extra ascos facile in articulos secedentes.

Hab. in axillis foliorum semper ad nodos culmorum Trachypogonis plumosi, prope Pretoria, leg. Pole Evans, 9543 b.

Pseudosclerotia developing at the nodes of somewhat abnormal culms, which branch more freely than normal and have shorter internodes; often found at several successive, nodes.

The pseudosclerotium develops in the leaf axil, round a bud which usually consists of three leaflets; two of these, overlapping slightly, are closely adherent to the back of the sclerotium, against the sheath, the third, still more or less involute, is embedded in the fungous tissue. As the sclerotium develops, it may be straight, but frequently becomes arched, forcing the sheath away from the stem ; it is flattened cylindrical or horn-shaped 1-3 $\mathrm{cm}$. long, with broad base attached to the leaf sheath, $2-3 \mathrm{~mm}$. broad in the centre, tapering gradually to the apex, which may be free or enveloped in the sheath, surface black, white within. Stromata develop on the exposed side, that is, facing the stem, they are convex and vary in size, often covering the lower half of the sclerotium and extending towards the tip.

Internally the sclerotium is white, consisting of very closely interwoven hyphae, $2-2.5 \mu$ thick; this structure continues into the stroma, but at the surface of the latter, there is a firm, dark purplish-brown cortex, $25-30 \mu$ thick, covering the perithecia.

Perithecia immersed, oblong-lageniform, crowded, often compressed laterally or even irregular in form through mutual pressure ; total length $300-430 \mu$; ascigerous part oval 
to ellipsoid, 200-300 $\mu$ long, 70-120 $\mu$ diam., narrowed suddenly above into the ostiole. Ostiole cylindrical or narrow conical, straight or curved, not protruding, but fused with the cortex of the stroma, which is raised and hemispherical over the perithecium; ostiole traversed by a pore which is $15-20 \mu$ broad at the base, 12-15 $\mu$ at the apex, lined with numerous hyaline periphyses. Perithecial wall almost colourless, not sharply differentiated from the stroma, but separating the perithecia by 15-20 $\mu$. Asci numerous, long, cylindrical, rounded at the apex, tapering gradually at the base into a fine stalk, 6-8-spored, sp. part 150-200 $\mu$ long, ca. $5 \mu$ thick, thin-walled, thickened at the apex to $5 \mu$. Spores hyaline, slender, filiform, almost equalling the ascus in length, $1 \cdot 25-1 \cdot 5 \mu$ thick, pluriseptate, outside the ascus readily breaking into segments.

on Trachypogon plumosus Nees, Kaalfontein, Pole Evans, 9543 b, 9435, 10082, 28581 ; Johannesburg, Bottomley, 26607.

Urelytrum squarrosum Hack., near the old Standerton Road, Pole Evans, 8825.

? on Andropogon amplectens Nees, Meintjes Kop, Mogg, 25439.

Epichloe Volkensii P. Henn. [= Ophiodothis Volkensii (P. Henn.) Sace. ] described on Exotheca abyssinica from tropical Africa is probably a Balansia sp., and may possibly be identical with the fungus described on Trachypogon. According to the description, the stromata are somewhat similar but smaller, up to $1 \mathrm{~cm}$. long and $2 \mathrm{~mm}$. thick, perithecia subglobose, asci cylindrical, spores filiform. No measurements are given and the type was not available for comparison.

\section{Epichloe cinerea Berk and Br.}

Journ. Linn. Soc. 14 (1875) p. 111 (Fungi of Ceylon No. 982).

? Epichloe Zahlbruchneriana P. Hennings, Ann. Nat. Hist. Hofnus. Wien (1900) p. 1 ; Sace. Syll. Fung. XVI : 607.

Epichloe Eragrostis Pole Evans, Ann. Bolus Herb. 2 (1918) p. 110.

Stromata usually enveloping and destroying the whole intlorescence, but occasionally partly developed spikelets can be seen incompletely covered by fungous tissue. Stromata sub-cylindrical, tapering to the apex, usually $4-8 \mathrm{~cm}$. long and $2-3.5 \mathrm{~mm}$. thick; or sone hosts, e.g. Bewsia, shorter, 2-3 cm. long. Stroma white within; surface grey, smooth or somewhat verrucose to the naked eye; with a hand lens, the surface appears most frequently ashen grey, occasionally darker, rarely smooth, when dry traversed by undulating and anastomosing, more or less longitudinal grooves; rather closely set with punctiform ostioles, which are more or less seriate on ridges between the grooves, convex, protruding, shiny black, round to oval.

The centre of the stroma consists of a close fungous tissue, consisting of closely interwoven, fine, hyaline hyphae ; in this are included the broken-down remnants of host tissues, the vascular elements being more or less intact. Towards the periphery, the stroma tissue is slightly tinted, and near the surface forms a cortex of still closer texture, greyish-fuscous to olive-grey in colour; there is a thin hyaline layer outside this cortex, which gives the stroma its characteristic grey colour.

Perithecia formed in large numbers in one layer near the periphery, flask-shaped, $250-$ $350 \mu$ long, including the ostiole, which is $90-100 \mu$ long ; ascigerous part elli psoid to subglobose, $150-220 \mu$ high, $90-170 \mu$ broad. The ostiole protrudes slightly, but at the periphery is continuous with, and fused with the cortex of the stroma, which becomes convex at this point. Ostiole traversed by a pore, which is cylindrical or narrow conical, $25-40 \mu$ broad at the base, 10-20 $\mu$ at the apex, lined with numerous hyaline periphyses. Asci fasciculate, cylindrical, rounded at the apex, tapering to the base, straight or curved, 6-8-spored, sp. part 90-175 $\mu$ long, 4-6 $\mu$ diam., mostly about $150 \times 6 \mu$, thin-walled, thickened at the apex. Spores filiform, slightly curved, very variable in length, 35-87.5 $\mu$ long, rarely more than 
$65 \mu$ long, 1-1.25 $\mu$ thick, hyaline, 3-7-septate, tapering gradually to the apex and slightly to the base, readily breaking apart at the septa ; the segments, which are often $20-30 \mu$ long, are distinguishable from the shorter spores by their truncate ends.

on Bewsia biflora Goosens, Rietvlei, Pretoria district, Murray and Acocks, 30249 ; Fountains Valley, Mogg, 11334; Kaalfontein, Pole Evans, 9543 a. Ctenium concinnum Nees, Himeville, Storey, 32495.

Digitaria Brazzae Stapf, Marandellas, Rattray (Rh. 1855) 30111, det. Mason.

Digitaria diagonalis Stapf, Groenkloof, Pole Evans, 11871.

Eragrostis chloromelas Steud., Pretoria, Pole Evans, 9159.

Eragrostis curvula Nees, Umzimkulu, Browne, 9688.

Eragrostis plana Nees, Kentani, Pegler, 2076, 2139, 2190; Tabamblope, West, 30519 ; Mooi River, Mogg, 10063, 10076 ; Bot. Gardens, Durban, Kent, 15455 ; Moedig Siding, Mainpri:e, 28538 ; Tweedie, Mogg, 10066.

Eragrostis robusta Stent, Hopevale, Morgan, 27749.

Eragrostis sclerantha Nees, Donkerpoort, Doidge and Bottomley, 29761.

Eragrostis spp., Durban, Baker, 32016 ; Vereniging, L. C. Turner, 8977.

Microchloa caffra Nees, Groenkloof, Pole Evans, 11872.

Panicum natalense Hochst., Roberts Heights, Mogg, 33431.

Setaria nigrirostris Dur. and Schinz, Groenkloof, E. P. Phillips, 14248.

Sporobolus capensis Kunth., Acton Homes, L. A. Doidge, 25897 ; Eshowe, Gerstner, 28580 ; Lidgetton, Mogg, 11637 ; Thorneville Junction, Doidge, 865.

Tristachya Rehmanni Hack., Kaalfontein, Pole Evans, 9542.

on grass undet., Natal, Medley Wood 3959; Donnybrook, Gordon, 30790 ; Cramond, Pole Evans, 1369, 1395; Lidgetton, Mogg, 11639; Fairy Glen, Lounsbury, 17051 ; Skinner's Court, nr. Pretoria, Pole Evans, 745 ; Fountains Valley, Mogg, 11335 ; Orange Free State, Nobbs, 20910; Basutoland, Dieterlen, 11715, 18025; Mt. Insizwa, Krook (R. Penther 2205, Type of Epichloe Zahlbruckneriana P. Henn.).

Epichloe occurs in South Africa on a wide range of grass hosts, but has not been found on any species of the Andropogoneae, which form a large proportion of the indigenous grasses. Numerous collections have been examined, and 12 numbers on various hosts studied in detail. The fungus appears to be most common in Natal and the eastern part of the Cape Province on species of Eragrostis and on Sporobolus capensis; the latter host is often so severely affected that it is difficult to find a normal flowering head.

I am indebted to Mr. E. W. Mason for notes on collections of Epichloe from Africa in the herbarium of the Imperial Mycological Institute and in Kew Herbarium. In a letter dated the 4th April, 1943, he writes:-

"I have just compared this specimen (on Digitaria Brazaae, J. C. Hopkins, 1855) with three other specimens in our herbarium identified as above; they are (1) on Sporobolus pyramidalis from the Gold Coast; (2) on Setaria aurea from Kenya, and (3) on Trichopteryx sp. from Uganda (Maitland 470). They all seem to me identical in stromata, asci and ascospores with one another and with Thwaites 509 on Eragrostis nutans from Ceylon (in Herb. Kew) which is the type of Epichloe cinerea Berk and Br.

"Revised descriptions of the species have been given by Petch (Ann. Roy. Bot. Gard. Peradinya VI, Pt. 2, p. $173:$ 1916) from the co-type, and by Sydow and Butler (Ann. Myc. IX, p. 394 : 1911) from Indian material, which, however, is not available here.

"I am not quite sure how the asci and spores should properly be described. In all the specimens, the asci vary in length from about $90-150 \mu$ long, and are very close to 
$4 \mu$ broad. In the shorter asci, the ascospores appear to be the length of the ascus, but free ascospores $150 \mu$ long have not been observed. They are generally freed in portions $20-30 \mu$ long, but this may be due to rough handling.

"From a note in our Herbarium, the asci of Epichloe Eragrostidis Pole Evans from South Africa (in Herb. Kew) on Eragrostis plana show about the same variation."

A careful examination of numerous spores from fresh material indicates that the spores are not as long as the ascus, as stated by Petch and by Sydow and Butler (l.c.) except possibly in the shorter asci; the maximum length observed was $87 \cdot 5 \mu$. The hyaline, filiform spores are slightly twisted together in the ascus and it is impossible to measure the length accurately until they are free; they are rarely more than $65 \mu$ long and taper slightly to both ends, more gradually to the apex; they are thus distinguishable from the segments with truncated ends.

No. 14248, on Setaria nigrirostris was listed by Doidge and Bottomley (Bot. Survey S. Africa. Memoir 11, p. 26 : 1931) as Epichloe Zahlbruckneriana P. Henn., a species described by Hennings (l.c.) from culms of an unidentified grass found in iriqualand East. The description of the stroma of this fungus does not differ in any essential from that of Epichloe cinerea; the asci are said to be $150-220 \mu$ long, measurements which possibly include the sterile tapering base, in which case the sporiferous part would not exceed $175^{\circ} \mu$ in length ; ascospores are said to be $0 \cdot 5-0 \cdot 8 \mu$ thick, slightly thinner than the measurements given above, which were made from spores which had been immersed in 5 per cent. lactic acid. There is little doubt that E. Zahlbruckneriana is identical with E. cinerea, but unfortunately the type has not been available for comparison.

The conidial stage described by Hennings has not been observed, but Pole Evans' "stromatibus primo rubicundis conidiophoris" evidently refers to the conidia-bearing mycelium of Fusarium ciliatum, which is frequently found covering large areas of the Epichloe stroma.

\section{Neopeckia Caesalpiniae Doidge nov. spec.}

Perithecio in subiculo late effuso ex hyphis brunneis $4-5 \mu$ crassis rigidis, longis, septatis, cellulis 15-20 $\mu$ longis, simplicibus, interdum paullum fasciculatis, rectis $\mathrm{v}$. divergentibus vix repentibus insidentes; primo gregaria v. confertula, deinde densissime aggregata, obovoidea v. sphaeroidea, vel mutua pressione paulum irregularia, vertice applanata $\mathrm{v}$. late rotundata, pilis rigidis, flexuosis saepe genuflexis, brunneis, ad apicem pallidioribus, hyphis mycelii similibus undique nisi ad apicem vestita, nigra, carbonacea, $350-500 \mu$ alta, 280-360 $\mu$ diam. Asci numerosi, 8-spori, cylindracei, sursum rotundati, deorsum plus minus longe pedicellati, $100-125 \times 10-11 \mu$, p. sp. Sporae oblique monostichae, ellipsoideae, utrinque late rotundatae $v$. sensim attenuatae, 1-septatae, leniter v. vix constrictae, diu hyalinae demum fuscidulae, $16-24 \times 6-7 \cdot 5 \mu$, cellulis subequalibus $v$. superiore breviore et latiore. Paraphyses numerossimae, filiformes, ramosae, ascos superantes.

Hab. in ramulis dejectis Caesalpiniae sepiariae, Town Bush Valley, leg. Doidge, 34480.

Subiculum developing and spreading on the wood, sometimes covering areas up to $2.5 \mathrm{~cm}$. diam., consisting of long, rigid hyphae, olive-brown to buffy-brown, $4-5 \mu$ thick and with cells $15-20 \mu$ long, simple or somewhat fasciculate, straight or divergent, rarely creeping.

Perithecia may be based on decorticated wood, but, when the papery bark has not fallen, the subiculum penetrates to the surface and the perithecia develop on the bark. Perithecia from the first closely grouped, then becoming very densely crowded. They form an almost continuous crust which, if developed on the wood, extends over an area up to $2.5 \times 1.5 \mathrm{~cm}$.; or, if on the bark, covering more restricted areas, usually $5-7 \times$ 3-6 mm. Perithecia black, carbonaceous, obovoid or globose, or slightly irregular through mutual pressure, broadly rounded or almost flat at the apex, cupulate when dry, $350-500 \mu$ high, $280-370 \mu$ diam. Except for the apex, the perithecial wall is clothed with rigid hairs, $25-150 \mu$, rarely up to $200 \mu$ long, 4-5 $\mu$ thick, similar to the mycelial hyphae ; they are 
more numerous, and usually longer, towards the base of the perithecium, flexuous or geniculate; paler and more closely septate towards the apex, where they are rounded or slightly distended and subclavate (5-6 $\mu$ thick). Ostiole flat, almost crateriform, or rarely very broadly truncate conical ; the ostiole usually breaks away, and the broken edges form the rim of a flat, circular pore. Perithecial wall rough, consisting of several layers of flattened, polygonal cells, $4 \cdot 5-12.5 \mu$ diam., of which the outer layers are olive-brown, thick-walled and to which the hairs besetting the perithecium are attached. The inner layers are thinwalled, shading to dark olive-buff. The cells composing the ostiole are smaller.

The base of the perithecium is filled with a hyaline weft of fungous tissue, of which the structure is not evident and on which the asci and paraphyses are borne. Asci numerous, 8-spored, narrow-cylindrical, straight or curved, rounded at the apex, tapering to a rather long foot at the base, sp. part 100-125 $\times 10-11 \mu$; wall tough, ca. $1 \mu$ thick, slightly thickened at the apex, $2 \cdot 5-3 \mu$.

Paraphyses very numerous, hyaline, filiform, flexuous, branched, exceeding the asci.

Spores obliquely monostichous, variable in form, ellipsoid, sub-clavate or sub-fusoid, broadly rounded at both ends or tapering somewhat, 1-septate, slightly constricted at the septum or barely so, $16-24 \times 6-7 \cdot 5 \mu$. Cells sub-equal, or, in the sub-clavate spores, the upper somewhat shorter and broader than the lower; in clavate spores $20-22.5 \mu$ Iong, the upper cell was 9-10 $\mu$ long and 7-7.5 $\mu$ broad, the lower 11-12 $\times 6 \mu$.

on fallen branches of Caesalpinia sepiaria Roxb., Town Bush Valley, Doidge, 34480.

\section{Englerula Macarangae P. Henn.}

Engl. Not. Jahrb. 34, p. 49 (1905).

Sacc. Syll. Fung. XVII : p. 529 ; Petrak, Aun. Myc. XXVI : p. 387 (1928).

Not on leaf spots; colonies hypophyllous, scattered, round to irregular in outline, up to $6 \mathrm{~mm}$. diam., rarely larger. Mycelium ahyphopodiate, more or less reticulate; closely reticulate in the centre of the colony, loosely reticulate near the margin. Hyphae buffyolive to olive-brown, translucent, more or less deeply undulating, seldom almost straight, $2-4 \mu$ thick, main hyphae occasionally $5-6 \mu$ thick ; sometimes two or more hyphae running parallel from strands.

Perithecia develop in the centre of the colony, often in groups of two or more which may be closely crowded, remaining discrete or becoming fused at the base, sub-globose or globose-ovoid, without ostiole. When immature, perithecia are $30-40 \mu$ diam., darkolive-brown at the base, paler above, consisting of roundish angular, rather thick-walled cells $3 \cdot 5-6 \mu$ diam., seldon up to $7 \mu$; at maturity becoming mucose-diffluent and swelling up to a diameter of $100-200 \mu$. The wall becomes pale and translucent, and the asci are - clearly visible. Asci few, usually 3-6, ovate, broadly clavate or oblong-ovate, broadly rounded at the apex, tapering slightly to the base which is sessile or apiculate and sometimes curved, 8-spored, wall tough and 2-2.5 $\mu$ thick, thickened $(5-10 \mu)$ at the apex, $60-80 \times 35-50 \mu$. Spores distichous or imperfectly tristichous, oblong or oblong-clavate, broadly rounded at both ends, broader and more broadly rounded at the upper end, 1-septate, more or less constricted at the septum, long remaining hyaline, becoming buffy-olive ; almost opaque, blackish-brown when mature, 25-36 $\mu$ long; cells equal length, the upper cell more or less ovoid, $15-17 \cdot 5 \mu$ broad, lower cell narrow ovoid or almost truncate conical and about 1-1.5 $\mu$ narrower than the upper.

Pycnidia (Oothecium Macarangae Petrak) round, very variable in size, mostly 30-100 $n$ diam., membrane becoming mucose-diffluent near the apex when mature. Conidia in smallest pycnidia single or few ; more or less numerous in the larger pycnidia. Conidia ovoid, ellipsoid, almost globose or oblong-clavate, broadly rounded above, often tapering somewhat to the lower end, which is rounded to truncate, 1-celled, $20-35 \times 15-20 \mu$, buffybrown to blackish-brown, with a dark spot at each pole, surrounded by a paler, almost hyaline zone. The conidia germinate at the poles.

on leaves of Macaranga capensis Benth., Eshowe, Laughton, 34112. 
This is a tropical African species, recorded from tropical East Africa and from the Belgian Congo. This is the first time that it has been found as far south as Zululand. The polar zone in the conidia seems to correspond with the equatorial pale or hyaline zone found in many Asterostomella conidia and in conidia of Oothecium stylosporum (Cke.) Doidge (Bothalia 4, Pt. 2, p. 327).

\section{Didymella zuluensis Doidge nov. spec.}

Perithecia ramulicola, in maculis subatris irregulariter circularibus v. oblongis, 1-2 mm. latis, subinde saepe confluentibus et longioribus gregarie innata, globoso-depressa, 120$170 \mu$ diam., 90-112 $\mu$ alta, atra, epidermide quasi clypeiformiter denigratula tecta ; ostiolo breviter conoideo haud prominulo $12-15 \mu$ lato pertuso; pariete atro-brumneo, 10-12 $\mu$ crasso, contextu obscure parenchymatico. Asci numerosi, 8-spori, oblongi, firme crasseque tunicata, antice rotundati, sessiles v. brevissime pedicellati, $45-55 \times 6-7.5 \mu$. Sporae distichae, subfusoideae, utrinque leniter attenuatae, rotundatae, 1-septatae, haud constrictae, hyaline, $11-14 \times 3-4 \mu$.

Hab. in ramulis Eugeniae zuluensis in sylvis Xumeni, prope Donnybrook, leg. Morgan and Doidge, 29840.

Perithecia rather loosely grouped on twigs, immersed, covered by the epidermis, which becomes slightly convex and discoloured dark brown to black. The perithecia are thus grouped on dark spots which are at first irregularly round to oblong and 1-2 mm. diam.; these often become confluent, forming larger groups, which usually take the form of narrow, simple or branched, irregular ribbons running round the twig or diagonal to the axis.

Perithecia flattened globose, $120-170 \mu$ diam., $90-112 \mu$ high ; the host tissue on either side of the perithecia is permeated by dark brown hyphae $2-2 \cdot 5 \mu$ thick and the cell walls are discoloured dark brown; the epidermal cells become black and opaque and almost clypeiform in appearance. Ostiole conical, not protruding, 25-45 $\mu$ long, ca. $35 \mu$ broad at the base, at the apex opening by a more or less circular pore $12-15 \mu$ diam. Perithecial wall dark brown, subopaque, $10-12 \mu$ thick, obscurely parenchymatous, giving place suddenly within to a hyaline layer of equal thickness. Asci numerous, oblong, 8-spored, rounded above, tapering slightly at the base, sessile or very briefly pedicellate, with a firm thick wall, ca. $1 \mu$ thick, slightly thickened at the apex, 45-55 $\times 6-7.5 \mu$. Spores distichous, subfusoid, tapering slightly to rounded ends, hyaline, 1-septate, not constricted at the septum, 11-14 $\times 3-4 \mu$; cells equal in length or nearly so, but the upper cell is often slightly broader than the lower; spores conspicuously biguttulate.

on Eugenia zuluensis Dummer, on twigs, Xumeni Forest near Donnybrook, Morgan and Doidge, 29840.

\section{Leptosphaeria Pterocelastri Doidge nov. spec.}

Maculae amphigenae, rotundatae vel irregulares, 5-10 mm. diam., interdum majores, in pagina folii superiore cinerascentes margine olivaceo-brunneo limitatae, in inferiore avellaneae. Perithecia epiphylla sparsa, parenchymate immersa, epidermide tecta dein ostiolo papillato tenuissime prominula, globosa $\mathrm{v}$. globoso-depressa, 200-250 $\mu$ diam., 125-185 $\mu$ alta, contextu parenchymatico, pellucido, olivaceo-brumneo, ex cellulis compressis 10-15 $\times 2 \cdot 5-5 \mu$ composito. Asci octospori, cylindracei, recti v. curvati, apice rotundati incrassati, brevissime crasseque pedicellati, plerumque ex basi perithecii evoluti, $75-100 \times$ 7.5-10 $\mu$, paraphysati. Sporae oblique monostichae, oblongae, utrinque late rotundatae, 2 -septatae, rarissime 3 -septatae, ad septa haud constrictae, rectae v. vix inaequilaterae, olivaceae, $14-16 \times 6-7 \mu$.

Hab. in foliis Pterocelastri tricuspidati, Knysna, leg. E. M. Laughton, 35142.

Leaf spots dry, round to irregular in outline, often marginal, 5-10 $\mathrm{mm}$. diam., occasionally larger; on the upper surface pale olive-grey with olive-brown border, avellanous on the under side of the leaf. 
Perithecia epiphyllous, scattered or subgregarious, innate in the mesophyll of the leaf, the apex of the ostiole only rupturing the epidermis, but barely protruding. Perithecia globose or flattened-globose, 200-250 $\mu$ diam., 125-185 $\mu$ high. Wall membranaceous, deep olive, ca. $10 \mu$ thick at the base, consisting of several rows (four or more) of flattened, thin-walled cells $10-15 \mu$ long and $2 \cdot 5-5 \mu$ thick, paler and less distinct in structure above. Ostiole deep olive at the apex, papillate or truncate-conical, lined with fine, hyaline periphyses, pore indistinct.

Asci 8-spored, arising from the base of the perithecium, cylindrical, straight or eurved, rounded and slightly thickened at the apex and with a very short thick foot, $75-100 \times$ $7 \cdot 5-10 \mu$. Paraphyses hyaline, exceeding the asci. Spores monostichous, slightly oblique, oblong, straight or somewhat asymmetrical, broadly rounded at both ends, often somewhat flattened at each pole, 2-septate, very rarely 3-septate, not constricted at the septa, 14-16 $\times 6-7 \mu$, at first hyaline, then dark olive-buff, olive-brown when fully mature.

on leaves of Pterocelestrus tricuspidatus Sond., Knysna, E. M. Laughton, 35142.

C'losely associated, on the same leaf spots, with Pestalotia Pterocelastri Laughton, and with other fungi.

227. Mycosphaerella Agapanthi (Kalchbr. and Cooke) Landau.

in Engler and Prantl, Naturl. Pflanzenfam. 1 Teil, 1 Abt. (1897) p. 427.

Sphaerella Agapanthi Kalchbr. and Cooke, Grevillea 9 (1880) p. 31.

Perithecia developing on leaf spots, which are at first light brown, poorly defined, scattered over the leaf surface, elliptic and up to $4 \mathrm{~mm}$. long. The leaf spots increase in size and become smoke-grey as the perithecia develop, often running together, especially near the leaf tips and covering large areas of the leaf surface.

Perithecia closely and irregularly set in the leaf spots, shining black, round, punctiform, discrete or in small, close groups of $2-4$, rarely more ; developing under the epidermis and becoming more or less erumpent, flattened globose, 80-100 $\mu$ diam., $60-75 \mu$ high ; ostiole very short, $10-15 \mu$ long, broadly and truncately conical, periphysate within and with a more or less round pore ca. 15-20 $\mu$ diam. Perithecial wall firm, membranous, composed of several lavers of large, blackish-brown, pellucid, thin-walled, roundish-angular or somewhat elongated cells, $7 \cdot 5-12 \cdot 5 \times 7 \cdot 5-10 \mu$; the cells are compressed laterally to a thickness of $2 \cdot 5-5 \mu$; wall $7 \cdot 5-12 \cdot 5 \mu$ thick at the base, sometimes only slightly thicker above, sometimes spreading out on either side to a radius of $30 \mu$ just under the cuticle, and around the ostiole which protrudes only slightly. On the outside, the perithecial wall is connected with hyphae which penetrate right through the leaf tissues; these hyphae are fuscous, mostly $\bar{j}-6 \mu$ thick, frequently branched and septate and more or less tortuous. Within the perithecial wall, the ascigerous laver is quite hyaline.

Asci not very numerous, ovate or ellipsoid, straight or curved, rounded at both ends, often broader and more broadly rounded at the base and tapering somewhat to the apex, sessile or with a very short, knob-like foot, 8 -spored; wall thin, $1 \mu$ or less, but firm, slghtly thickened $(2-\overline{5} \mu)$ at the apex. Spores distichous, hyaline, oblong or oblong-clavate, rounded at both ends, often slightly broader above, tapering slightly and gradually downwards, more or less equally 1 -septate, not constricted at the septum or barely so, $15-20 \times 4-5 \mu$, mostly ca. $17 \cdot 5 \times 5 \mu$.

on Agapanthus africanus Hoffm., on leaves, Kentani, Pegler 2366, 9167 ; Durban, van der Byl, 31954 a.

The original collection is MacOwan 1342, collected at Somerset East. The portion of this collection in the Pretoria herbarium is labelled Pleospora herbarum Rabenh.; unfortunately this material is in very poor condition and quite unfit for study. There are no asci nor spores, these having apparently been destroyed by bacteria, and even the perithecia 
are partly broken down. The fungus has been re-described from No. 9167. The spores are somewhat larger than stated by Kalchbrenner and Cooke $(15-18 \times 3 \mu)$, but possibly the material which they examined was not quite mature.

\section{Mycosphaerella Moelleriana (Thuem.) Lindau.}

in Engler and Prantl, Naturlich. Pflanzenfam. 1 Teil, 1 Abt. (1897) p. 425.

Perithecia on light brown or greyish-brown leaf spots, which are round to irregular in outline, up to $10 \mathrm{~mm}$. diam., becoming dry and surrounded by a narrow raised margin of a darker brown. These spots are scattered, but often numerous, becoming coalescent and thus larger and very irregular in outline ; in extreme cases the greater part of the leaf surface is involved.

Perithecia amphigenous, but mostly hypophyllous, usually very numerous, closely and irregularly grouped; less frequently only a few perithecia develop on each spot. Perithecia at first immersed, covered by the slightly raised epidermis, shining black, punctiform; later the epidermis ruptures and they are more or less exposed, or it remains covering the perithecia, which are then punctiform-erumpent only by means of a papillate ostiole. Perithecia minute, globose, $75-90 \mu$ diam. Perithecial wall 10-12 $\mu$ thick, dark brown, membranous, composed of several layers of thin-walled, brown, polygonal cella, $5-10 \mu$ diam.; these are somewhat compressed laterally and ca. $2.5 \mu$ thick. Ostiole verruciform, not prominent in erumpent perithecia, papilliform in those which remain covered by the epidermis and up to $20 \mu$ long, 15-20 $\mu$ broad and traversed by a more or less circular pore ca. $10 \mu$ diam. Asci fasciculate, obovate to obclavate, broadest near the base, tapering somewhat to both ends, but more definitely towards the rounded apex, 8-spored, sessile or sub-sessile, with a firm thick wall, $30-40 \times 12-15 \mu$. Spores distichous, oblong-clavate, hyaline, rounded at both ends, but more broadly rounded above and tapering gradually downwards, equally or sub-equally 1-septate, not constricted at the septum or barely so, upper cell somewhat broader than the lower, $10-13 \times 2-3 \mu$.

on Eucalyptus gigantea Dehnh., Hogsback, 20620.

Eucalyptus globulus Lab., Cedara, 26116, 26117, 26118, 26131 ; Natal Native Trust Forests, 26125 ; Hilton Road, 26127, 26128; Merrivale, 26129, 26130 ; Krugersdorp, 32202.

Eucalyptus Maidenii F. Muell., Birnham Woods, Merrivale, 26126; Berlin, Cape, 23664 ; Cedara, 26119 ; Jessievale, 26107.

Eucalyptus saligna Sm., Natal Native Trust Forests, 26123.

Eucalyptus Stuartiana F. Muell., Cedara, 26120.

Eucalyptus tereticornis Sm., Natal Native Trust Forests, 26124.

Eucalyptus sp., Harding, Wilding, 28787.

The above specimens were all collected by officers of the Forestry Department, the majority by the Forester at Cedara. A number of the collections show only immature perithecia, others are in good condition, the best material being Nos. 26112, 26123 and 26124. A collection on Eucalyptus corynocalyx F. Muell. and one on Eu. maculata Hook., both from Cedara, are probably the same fungus, but the perithecia are undeveloped. The characters and measurements of the fungus agree very closely with those given in the Sylloge Fungorum I : 491, a detailed study having been made of three collections in three different species of Eucalyptus.

In the South African Journ. Science 30 (1931) p. 227, Mycosphaerella Moelleriana is described by Verwoerd and du Plessis; they found the perithecia considerably larger (Perithecia 163-248 $\mu$, asci 34-43 $\times 6-7 \mu$ and spores 10-20.5 $\times 3 \cdot 4-1 \mu$ ). This form would appear to be intermediate between the typical $\boldsymbol{M}$. Moelleriana and var. megalospora da Camara (Syll., Fung. XXII : 125) with asci 50-60 $\times 18-20 \mu$ and spores $20-25 \times 6-8 \mu$. 
According to observations made by Forest officers, Eucalyptus globulus is more susceptible to attacks by this fungus than other species. In December, 1930, it was noticed that leaf spots were very numerous in some stands of this species of Eucalyptus and that they were beginning to develop in others; at this time, some of the very young coppice shoots had been almost completely defoliated; by February the position was worse and there was much defoliation in the young coppice growth. The fungus attacked chiefly developed juvenile leaves; leaf spots were rare on leaves which still retained their juvenile glaucous covering and on semi-mature leaves ; leaf spots develop rapidly on coppice growth after a rain or a few days of mist, especially if a spell of hot weather follows a good rain.

\section{Mycosphaerella Plectranthi Doidge nov. spec.}

Maculae amphigenae, sparsae, distinctissimae, orbiculares v. irregulares, saepe confluentes, pallide brunneae, usque $3.5 \mathrm{~mm}$. diam. Perithecia semper epiphylla, pauca, irregulariter laxeque dispersa, sub epidermide evoluta, tandem sublibera, globosa, $75-85 \mu$ diam.; ostiolo plano papilliformi tandem poro rotundo $10-12 \mu$ aperto ; pariete 5-10 $\mu$ crasso, e stratis 2-3-cellularum rotundato- vel irregulariter angulatarum pellucide olivaceobrunnearum 5-7.5 $\mu$ diam., 2.5-4 $\mu$ crassarum composito, intus subito in contextum hyalinum fibrosum transeunte. Asci sat numerosi, ellipsoidei v. clavati, antice late rotundati, postice leniter attenuati, subsessiles v. breviter crasseque pedicellati, 8-spori, p. sp. 32.5-40 $\times$ 7-9 $\mu$. Sporae distichae, oblongo-fusoideae vel subclavatae, utrinque obtuse rotundatae, antice vix vel leniter, postice distincte attenuatae, rectae v. subrectae, circa medium septatae, vix constrictae, hyalinae, $10-13 \times 2-2.5 \mu$. Paraphyses haud visae.

Hab. in foliis Plectranthi fruticosi, in sylvis Knysna, leg. Bottomley, 32253.

Perithecia on leaf spots, which are very well defined, scattered or often confluent, visible on both sides of the leaf, round to irregular in outline, light brown, up to $3.5 \mathrm{~mm}$. diam. Perithecia always epiphyllous, not numerous, irregularly scattered on the leaf spots and usually distant from one another, at first immersed, later becoming more or less free, globose, $75-85 \mu$ diam. ; ostiole short, flat, papilliform, 15-18 $\mu$ long, with a more or less round pore, $10-12 \mu$ diam. Perithecial wall 5-10 $\mu$ thick; at the base consisting of 2-3 layers of angular, more or less round or irregular cells, pellucid olive-brown, $5-7 \cdot 5 \mu$ diam., somewhat flattened and $2 \cdot 5-4 \mu$ thick ; towards the ostiole the wall is somewhat thicker. Asci fairly numerous, ellipsoid or clavate, straight or curved, broadly rounded above, tapering slightly to a briefly pedicellate base, 8-spored, sporiferous part $32 \cdot 5-40$ $\times 7-9 \mu$. Spores distichous, hyaline, oblong-fusoid or sub-clavate, tapering very slightly to the upper end, more definitely to the lower end, more or less equally septate, very slightly constricted at the septum, upper cell often slightly broader, especially just above the septum, often slightly curved, $10-13 \times 2-2.5 \mu$. Paraphyses not seen.

on Plectranthus fruticosus L'Herit., on leaves, Knysna, Bottomley, 32253.

\section{Physalospora Sapii Doidge nov. spec.}

Perithecia amphigena, plerumque hypophylla, sine maculis sed decolorationes inteterminatas efficientia, laxe dispersa, epidermide obtecta, globoso-depressa, 100-150 $\mu$ diam., 85-100 $\mu$ alta, poro pertusa ; pariete membranaceo variabile crassitudine, e stratis numerosis cellularum composito, cellulis sat compressis, rarius globoso-angulatis, $4-15 \mu$ longis, $5-10 \mu$ latis tenuiter tunicatis, extus brunneis intus hyalinis. Asci clavati, recti v. curvati, 8 -spori, crasse tunicati (ca. $1 \cdot 5 \mu$ ) ad apicem leniter incrassati, $2 \cdot 5-3 \mu$, superne late rotundati, inferne sensim attenuati, breviter pedicellati, 40-50 $\times 10-12.5 \mu$. Sporae distichae, hyalinae, fusoideae, continuae, utrinque obtusae v. truncatae, 12-15 $\times 4-5 \mu$. Paraphyses paucae mox mucoıae.

Hab. in foliis Sapii reticulati, Eshowe, leg. Laughton, 33543.

Perithecia amphigenous but mostly hypophyllous, not on leaf spots, but causing a vague discolouration of the leaf tissues, scattered, usually distant, at first completely immersed 
and covered by the epidermis, which becomes raised and convex over the perithecia ; later more or less erumpent. Perithecia flattened-globose, 100-150 $\mu$ diam., 85-100 $\mu$ high, at first closed, then opening by an apical pore, not papillate. Perithecial wall varying in thickness; outer wall $12 \cdot 5-20 \mu$ thick, composed of a few, usually $2-4$, rows of indistinctly oblong, less frequently globose-angular, thin-walled, blackish-brown cells, 4-15 $\mu$ long and $5-10 \mu$ broad ; these give place internally to a number of rows of thin-walled, hyaline cells similar in form and finally to an indefinite concentric fibrose structure near the asci. Externally the perithecia are connected with rather sparse, smoke-brown hyphae, 4-6 $\mu$ thick, which penetrate between the cells of the host.

Asci 8 -spores, clavate, thick-walled, ca. $1 \cdot 5 \mu$ thick, broadly rounded above and somewhat thickened, $2 \cdot 5-3 \mu$, straight or curved, slightly attenuate to a pedicellate base, $40-50$ $\times 10-12 \cdot 5 \mu$. Spores distichous, fusoid, continuous, hyaline, tapering more or less to obtuse or truncate ends, sometimes asymmetrical, $12 \cdot 5-15 \times 4-5 \mu$. Paraphyses sparse, disappearing early.

on leaves of Sapium reticulatum (Hoschst.) Pax., Eshowe, E. M. Laughton, 33543.

\section{Pleospora Dyeri Doidge nov. spec.}

Perithecia irregulariter laxeque sparsa, plerumque solitaria, raro bina vel pauca aggregata, profunde immersa, depresso-globosa vel late ellipsoidea, 220-300 $\mu$ diam., $150-$ $200 \mu$ alta, ostiolo papillato vertice obtuso hyalino, $25-37 \cdot 5 \mu$ longo, poro irregulariter orbiculari 12-30 $\mu$ lato aperto punctiformiter erumpentia ; pariete membranaceo, $17-25 \mu$ crasso, parenchymatice e pluribus stratis cellularum angulatarum pellucide brunnearum, 6-15 $\mu$ metientum composito. Asci sat numerosi, clavati, antice late rotundati, postice sensim attenuati, breviter stipitati, firme crasseque tunicati, 6-8-spori, p. sp. $100-125 \times$ 40-45 $\mu$. Sporae distichae, oblongae v. ellipsoideo- oblongae, antice late rotundatae v. subacutae, postice rotundatae, medio leniter constrictae, 7-septate, cellulis 4-6 mediis septo quodam longitudinali praeditae, 42.5-50 × 18-20 $\mu$. Paraphyses vix numerosae, filiformes, hyalinae, ca. $1 \mu$ crassae, mox mucosae. 23615

Hab. in caulibus emortuis Euphorbia triangularis, prope Grahamstown, leg. R. A. Dyer,

Perithecia very widely distributed over the whole surface of the stem, which becomes light brown and dry, discrete or in more or less close groups of 2 or more, black, punctiform.

Perithecia deeply immersed, the epidermis becoming slightly raised and convex over each perithecium, flattened globose or broadly ellipsoid, $220-300^{\circ} \mu$ diam., $150-200 \mu$ high. Ostiole hyaline, papillate, obtuse at the apex, 25-37.5 $\mu$ long, punctiform erumpent by means of an irregularly round pore $12-30 \mu$ broad. Perithecial wall membranous, uneven outwardly where it is in close contact with the cells of the host and is connected with light fuscous to hyaline hyphae $2 \cdot 5-4 \mu$ thick, which penetrate into the stem tissues; wall 17-25 $\mu$ thick, composed of several layers of somewhat flattened, thin-walled, pellucid, purplish-brown, angular cells, 6-15 $\mu$ diam. Asci fairly numerous, up to about 16 in each perithecium, clavate, broadly rounded above, tapering gradually downwards and then constricted suddenly into a short, knob-like foot, $5-10 \mu$ long and about $10 \mu$ broad, with a firm wall, $1 \cdot 5-2 \mu$ thick, slightly thickened, 5-6 $\mu$, at the apex, 6-8-spored, sp. part 100-125 $\times 40-45 \mu$. Spores distichous, brown, oblong or ellipsoid-oblong, broadly rounded or subacute above, rounded below, at first transversely 3 -septate and slightly constricted at the septa, then 7 -septate; the central $4-5$ cells become also longitudinally septate; spores $42 \cdot 5-50 \mu$ long, the upper half broader, 18-20 $\mu$ thick, the lower 15-18 $\mu$ thick. Paraphyses not very numerous, filiform, hyaline, ca. $1 \mu$ thick, disappearing early.

on stems of Euphorbia triangularis Desf,, near Grahamstown, R. A. Dyer, 23615.

232. Anthostomella capensis Doidge nov. spec.

Maculae magnae saepe apicales, plus minus effusae, usque $15 \mathrm{~cm}$. longae, $1-2 \cdot 5 \mathrm{~mm}$. latae, pallide griseo-brunneae, linea marginali atrobrunnea limitatae. Perithecia amphi- 
gena, plerumque epiphylla, hinc inde in greges variae magnitudinis irregulares laxe interdum seriatim disposita, omnino innata, profunde in mesophyllo immersa, vix vel leniter depresso-globosa, 140-240 $\mu$ diam., 110-150 $\mu$ alta, praecipue in epiphyllo clypeo elliptico atrobrunneo usque $250 \mu$ longo, pro maxima parte in epidermide formato tecta ; ostiolo cylindraceo, $45-62 \cdot 5 \mu$ longo, $55-60 \mu$ crasso, intus copiose periphysato poro rotundo ca. $20-25 \mu$ lato pertuso, punctiformiter erumpentia ; pariete membranaceo, $9-12 \cdot 5 \mu$ crasso, e pluribus stratis cellularum valde compressarum extus dilute flavo-vel olivaceo-brunneloarum intus omnino hyalinum composito, ad apicem clypeo connato. Asci sat numerosi, cylindracei, antice late rotundati, postice subito in stipitem brevissinum contracti, tenuiter tunicati, 70-95 $\times 9-12 \mu$. Sporae oblique monostichae, oblongae v. ellipsoideae, utrinque haud vel vix attenuatae, late rotundatae, continuae, pellucide brunneae, sine appendiculis, 11-15 $\times 6-7 \mu$, lateraliter compressae e latere visae 4-5 $\mu$ crassae. Paraphyses sat numerosae, filiformes, mox mucosae.

Hab. in foliis Phoenicis dactyliferae, Port Elizabeth, leg. Doidge, 1236.

On leaf spots, usually spreading from the tips of the leaves to a length of several centimetres (up to $15 \mathrm{~cm}$.) and $1-2.5 \mathrm{~mm}$. broad, pale greyish or greyish-brown, the discoloured area being surrounded by a dark brown line.

Perithecia mostly epiphyllous, in groups of varying shape and size, sometimes more or less seriate, completely immersed, occupying one-half to two-thirds of the thickness of the leaf. Perithecia globose or somewhat flattened-globose, 140-200 $\mu$ diam., 110-150 $\mu$ high ; covered by a blackish-brown, elliptical clypeus, up to $250 \mu$ long, developed chiefly in the epidermis. Ostiole broad, cylindrical, 45-62.5 $\mu$ long, 55-60 $\mu$ broad, copiously periphysate, punctiform erumpent by means of a pore $20-25 \mu$ diam. and more or less round. Perithecial wall rather delicately membranous, 9-12.5 $\mu$ thick, formed of a number of layers of strongly compressed cells, outer layers pale yellow-brown or olive-brown, inner quite hyaline; at the apex fusing with the epidermal clypeus. Asci fairly numerous, cylindrical, broadly rounded above, at the base constricted suddenly into a very short foot, with a firm thick wall, $70-95 \times 9-12 \mu$. Spores obliquely monostichous, oblong to ellipsoid, not tapering to the rounded ends or very slightly so, brown, continuous, $11-15 \times 6-7 \mu$; compressed laterally, $4-5 \mu$ thick when seen from the side. Paraphyses fairly numerous, filiform disappearing early.

on leaves of Phoenix dactylifera Linn., Port Elizabeth, Doidge, 1236.

\section{Anthostomella Salaciae Doidge nov. spec.}

Perithecia longe lateque dispersa, decolorationes brunneas indeterminatas efficientia, greges minutes $\mathrm{v}$. majores irregulares plerumque formantia, discreta vel connata, plus minus depresse globosa, saepe leniter irregularia, 250-400 $\mu$ diam., omnino innata, fere totam folii crassitudinem occupantia, in utraque pagina epidermidem leniter pustulatim elevantia, tantum ostiolo obtuse saepe truncato-conoideo vel vix cylindraceo $100-180 \mu$ alto, in media parte $70-90 \mu$ crasso, intus poro rotundo $20-25 \mu$ lato pertuso, punctiformiter erumpentia; pariete firme membranaceo plerumque $20-30 \mu$ crasso, e stratis numerosis cellularum irregulariter $\mathrm{v}$. rotundato-angulatarum $2 \cdot 5-5 \mu$ diam. metientum, olivaceobrunnearum, plus minus pellucidum, ad vertice obscure brunnearum composito, cum epidermide fere clypeiformiter connato. Asci numerosi, cylindracei, antice rotundati, postice plus minus attenuati stipitati, tenuiter tunicati, ad apicem leniter incrassati $(4-\bar{\jmath} \mu)$, 8 -spori, p. sf. $100-125 \times 10-12 \cdot 5 \mu$. Sporae oblique monostichae usque subdistichae, oblongae, utrinque plerumque sat valide attenuatae, hinc saspe fusoideae, obtusae, haud appendiculatae, rectae v. inaequilaterae, continuae, pellucide olivaco-brunneae, plerumque $35-42.5 \times 5-7 \cdot 5 \mu$. Paraphyses numerosae, filiformes, ca. $1 \mu$ crassae, ascos superantes, sero mucosae.

Hab. in foliis Salaciae Gerrardi, Eshowe, leg. Laughton, 33546.

Perithecia distributed over large areas of the leaf surface, causing a rather vague brownish discolouration of the tissues, occasionally solitary, but more frequently in loose 
irregular groups of 2 to 20 , which are usually discrete but occasionally become confluent; groups of perithecia often in irregular series following the course of the veins of the leaf; the epidermis over the perithecia is greyish, with black pin points indicating the position of the ostioles.

Perithecia globose or flattened globose, often somewhat irregular in form, especially when in contact with a vein, $250-400 \mu$ diam., completely immersed, occupying practically the whole thickness of the leaf and raising the epidermis on either side. Ostioles obtusely and often truncately conical, occasionally cylindrical, 100-180 $\mu$ long and 70-90 $\mu$ broad in the centre, copiously periphysate within, punctiform erampent on the upper side of the leaf by a pore, which is usually $20-25 \mu$ diam. Ferithecial wall firmly membranous, formed of numerous lavers of roundish angular or irregular cells $2 \cdot 5-5 \mu$ diam., olive-brown, more or less pellucid, darker and often sub-opaque at the apex where it fuses with the discoloured epidermis; clypaus round ostiole sometimes poorly developed. Asci numerous, cylindrical, straight or curved, rounded above, 8-spored, sporiferous part 10-125 X $10-12 \cdot 5 \mu$, tapering at the base to a stalk ca. $25-40 \mu$ long; thin-walled, slightly thickened at the apex $(4-5 \mu)$. Spores obliquely monostichous to subdistichous, oblong or oblongfusoid, tapering more or less to both obtuse ends, straight or somewhat asvmmetrical, pellucid olive-brown, continuous, mostly $35-42 \cdot 5 \times 5-7 \cdot 5 \mu$, occasionally $45-50 \mu$ long. An occasional ascus was seen with ellipsoid spores $17-22.5 \times 10-10 \cdot 5 \mu$. Paraphyses numerous, filiform, about $1 \mu$ thick, exceeding the asci.

on leaves of Salacia Gerrardi Harv., Eshowe, E. M. Laughton, 33546.

234. Phyllachora eragrostidicola Doidge nov. nom.

Phyllachora Eragrostidis Doidge, Bothalia IV : 430 (1942) non Chandon.

on Eragrostis curvula Nees, Mamathes, Basutoland, Hean, 32428; and on other Eragrostis spp.

The name Phyllachora Eragrostidis was given in 1939 to an American species by Chandon (Bol. Soc. Venez. Cien, Natur, 40: 17). The original description has not been seen, but the species is recorded from North America by Orton in Mycologia 36 : 45, 1944. According to the description, the ascospores are $10-13 \times 4 \cdot 5-6 \mu$, smaller than those of the South African fungus, which are $12-15 \times 6-7 \cdot 5 \mu$.

\section{Diatrypella Morganae Doidge.}

Bothalia 4 (1941) p. 61.

on Citrus sinensis Osbeck, dead twigs of Valencia Late Orange, Mazoe, Bates (Bates $29 \mathrm{~L} / 5 / 19$ D) 33586.

The collection on citrus twigs cannot be distinguished from the type of Diatrypella Morgani, which was found on fallen wood in the indigenous forest in Natal. Part of the material on citrus is in excellent condition and the stroma better developed than in the type specimen.

For this collection and those cited under Nos. 235-237, I am indebted to Dr. G. R. Bates of the Citrus Experimental Station, Mazoe.

\section{Diatrypella natalensis Doidge.}

Bothalia 4 (1941) p. 60.

on Citrus sinensis Osbeck, twig of Valencia late Orange (Bates 29 T/10/16 A) Mazoe, 33583 ; branch of Valencia late Orange (Bates $\mathbf{M} / 26 \mathrm{~L} / \mathrm{A})$ Mazoe, 33581.

This species was originally described from a branch of Citrus nobilis collected in Natal. 
237. Peroneutypella infinitissima (Kalchbr. and Cooke) Doidge.

Bothalia 4 (1941) p. 64.

Valsa infinitissima Kalchbr. and Cooke, Greyvillea 9 (1880) p. 28.

on Citrus sinensis Osbeck, dead branch of Valencia Late Orange with bark, from Grove 26 L. Mazoe, Bates, 33587.

This collection is of interest ; the fungus was previously known only from MacOwans' original collection " on dead branches of undet. tree", Somerset East, MacOroan 1344 a.

\section{Valsaria Batesii Doidge nov. spec.}

Stromata sparsa vel plus minus aggregata, in cortice immersa, fere tantum cum ostiolis fasciculatim coalitis erumpentia, ambitu plus minus rotundata, hemisphaerico-pulvinata, $0 \cdot 5-1 \cdot 5 \mathrm{~mm}$. diam., valsoidea, inferne e hyphis brunneis $6-7 \cdot 5 \mu$ crassis composita, superne parenchymatice e cellulis atro-brunneis $3-5 \mu \mathrm{v}$. usque $10 \mu$ diam. metiontibus composita. Perithecia 5-25 in quoque stromate, monosticha, in stromate omnino immersa, conferta, ovoidea, oblongo vel e mutua pressione saepe applanata et irregularia, 200-250 $\mu$ diam., $300-400 \mu$ alta, superne subito in ostiola cylindracea, valde convergentia et apice in discum nigrum fasciculatim conjuncta attenuata; pariete $12 \cdot 5-15 \mu$ crasso, e pluribus stratis cellularum compressarum, pellucide olivaceo-brunnearum composito. Asci numerosissimi, cylindracei, p. sp. 75-85 $\mu$ longi, 9-10 $\mu$ lati, 8-spori. Sporae oblique monostichae, oblongae, utrinque late rotundatae, medio 1-septatae, haud vel vix constrictae, brunneae, leves, $9-14 \times 6-7 \cdot 5 \mu$, plerumque $12.5 \times 6 \mu$. Paraphyses numerosissimae, hyalinae, filiformes, undulatae, ca. $1 \mu$ crassae, ascos valde superantes.

Hab. in ramulis Cinnamomi camphorae, Salisbury, leg. G. R. Bates (Rh. 6762) 35296.

Stromata scattered or in small groups, immersed in the cortex, from which the apical disc becomes erumpent; or the bark may break away, exposing the stromata which remain seated on the decorticated wood.

Stromata usually hemispherical, black, pulvinate, with rough surface, $0 \cdot 5-1 \cdot 5 \mathrm{~mm}$. diam., contracted suddenly above into a disc 500-800 $\mu$ diam., through which the convergant ostioles of the perithecia pass; verrucose at apex of disc, through the presence of slightly protruding, black-shining ostioles. Occasionally, in small stromata, there is a very short disc, and the common ostiole of the perithecia, covered only by the cortex of the stroma, protrudes about $500-600 \mu$; occasionally, in larger stromata, the outer circle of convergent ostioles is only lightly covered in the disc and, with a hand lens, their course can be traced on the perimeter.

On the surface of the wood, there is a layer of horizontal hyphae, running parallel to the fibres of the host, extending far beyond the limits of the stroma and forming a black layer on the surface. They are dark olive-brown, 6-7.5 $\mu$ thick, frequently septate, with cells $10-25 \mu$ long; these give rise to hyphae which penetrate into the wood and are paler near the surface, hyaline where they penetrate more deeply into the tissues of the host.

The basal part of the stroma, between the host and the base of the perithecia, 300$400 \mu$ deep in the larger stromata, in the smaller sometimes only $75-100 \mu$, consists of a framework of horizontal hyphae, similar to those on the surface of the wood and running parallel to one another. The spaces between these main hyphae, usually narrow, but not infrequently wider and irregular in form, are filled with plectenchyma formed of paler, closely interwoven hyphae. At the margin of the stroma, the dark hyphae curve upwards, become closely interwoven and form, on the outside of the stroma and disc, a rather irregular, opaque black cortex, to which fragments of the cortical tissue of the host adhere. The upper part of the stroma consists of a dark, thin-walled pseudo-parenchyma of roundish or angular cells, 3-5 $\mu$ diam.; the cells of the disc are more loosely connected and become larger upward, up to $10 \mu$ diam. 
Perithecia 5-25 in each stroma, very closely crowded and not separated by stromatal tissue, circinate or arranged irregularly, oblong, ovoid or irregular in shape through mutual pressure, 300-400 $\mu$ high, $200-250 \mu$ diam.; contracted suddenly above into cylindrical ostioles, which are 500-600 $\mu$ long-in smaller stromata occasionally up to $1,200 \mu-$ strongly convergent, round to oval in section, $50-62 \cdot 5 \mu$ diam., lined with very numerous, ascending, fine hyaline periphyses. Ostioles usually becoming confluent, groups of 4-6 fusing into a common ostiole ca. $100 \mu$ diam., expanding to ca. $150 \mu$ at the apex, which is entire, not sulcate. Perithecial wall pellucid olive-brown, $12 \cdot 5-15 \mu$ thick, usually distinct from the stroma tissue and from the walls of adjoining perithecia, consisting of several lavers of thin-walled, flattened cells $7 \cdot 5-12 \cdot 5 \mu$ long, $2-2 \cdot 5 \mu$ thick.

Asci extremely numerous, lining the base and sides of the perithecial cavity, at sides reaching almost to the base of the ostiole, 8-spored, cylindrical, sp. part 75-85 $\times 9-10 \mu$, not staining blue with iodine. Paraphyses very numerous, hyaline, persistent, filamentous, slender, undulating, ca. $1 \mu$ thick, not staining blue with iodine. Spores obliquely monostichous, or oblique in the upper part of the ascus, vertical in the lower, oblong, hroadly rounded at both ends, olive brown, 1-septate, not constricted or barely so, smooth, 9-14 $\times 6-7.5 \mu$, mostly $12.5 \times 6 \mu$, cells equal or nearly so.

on twigs of Cinnamomum camphora Nees \& Eberm., Salisbury, 1945, G. R. Bates (Rh. 6762) 35926.

23!. Valsaria Eucalypti (Kalchbr. \& Cooke) Sacc.

Syll. Fung. I (1882) p. 746 ; Doidge, Bothalia 4 (1941) p. 66.

Melogramma Eucalypti Kalchbr. \& Cooke, Grevillea 9 (1880) p. 31.

on Citrus maxima Merr., on bark of Marsh grape fruit, unthrifty trees with incompatible bud unions (Bates P 22/A) Mazoe, 33588.

Prunus Armeniaca L., on bark, Pretoria, C. P. v. d. Merwe, 34120.

on dead branch of indigenous tree, Xumeni Forest, Morgan \& Doidge, 34123.

The collection on Citrus shows no significant difference from the type on Eucalyptus giobulus (Plate I.c.) The individual stromata are somewhat larger, and in structure they are rather more loosely woven ; the stromatal hyphae are $2 \cdot 5-3 \cdot 5 \mu$ thick near the perithecia and in the cortex, in the sterile part of the stroma they are 5-7.5 $\mu$ or even up to $8-10 \mu$ thick; some thicker hyphae are also to be seen in the stroma of the type specimen of V. Eucalypti. Stromata on Prunus and on an indigenous tree are similar, on the latter host varying from small stromata like those of the type to large cushions up to $4 \mathrm{~cm}$. long, $7 \mathrm{~mm}$. broad and $5 \mathrm{~mm}$. high.

Valsaria Eucalypti, with cinnamon brown, pulvinate stromata, is closely related to V. Cinnamomi (Ces.) Sacc.; the specimen of the latter species examined, on Eugenia grandis from Singapore (C. F. Baker, Fungi Malayana No. 496) 12164, is apparently part of the collection quoted in the Sylloge Fung. XXIV (1928) p. 764 ; it is very similar to the South African specimens, but the spores are consistently somewhat smaller, $10-11 \mu$ long, spores of $V$. Euralypti being predominantly $12 \cdot 5-14 \mu$ long, rarely $15 \mu$ long as previously stated (Doidge 1.c.); occasionally shorter spores $10-11 \mu$ long are seen ; spores $15 \mu$ long are rare.

Valsaria hypoxyloides Rehm is another similar fungus, and according to Rehm (see Theissen, Ann, Myc. X : 12, 1912) is probably identical with $V$. Cinnamomi. The spores of $\boldsymbol{V}$. hypoxyloides in the collection seen, from Porto Rico (Petrak, Myc. Gen. No. 100) 23336, are most frequently 14-15 $\mu$ long.

It has not been possible to examine type specimens of the two latter species, but it seems likely that there is only one rather variable species of Valsaria with the characters of $V$. Cinnamomi, namely pulvinate, cinnamon-brown stroma and verrucose spores without constriction at the septum. If this is the case, the correct name for the species would be Valsaria Cinnamomi (Ces.) Sacc., which was described by Cesati as Melogramma Cinnamomi in 1879. 
240. Protothyrium Tricalysiae Doidge nov. spec.

Mycelium liberum nullum. Stromata amphigena, plerumque epiphylla, ambitu plus minus rotundata $\mathrm{v}$. irregularia, usque $4 \mathrm{~mm}$. diam., plana, crustacea, opace atra, ex hypostromate epidermali hyalino oriunda, pluries affixa. Hypothecium continuum planum fuscum, $5-6 \mu$ crassum. Stratum tegens atro-brunneum, centro opacum, margine plus minus pellucide brunneum, ex hyphis subradiantibus vel fere maeandrice conjunctis, $4-6 \mu$ crassis, cellulis 12.5-20 $\mu$ longis formatum. Asci numerosi, erecti, per stroma dense dispersi, haud in loculis collecti, ovati v. oblongo-clavati, antice late rotundati et incrassati, postice plus minus attenuati, sessiles v. subsessiles, firme tunicati, 8-spori, $50-60 \times 20-25 \mu$. Sporae distichae v. subdistichae, oblongae, v. oblongo-clavatae, basim versus leniter et sensim attenuatae, 1-septatae, haud vel vix constrictae, leves, diu hyalinae, tandem subhyalinae v. dilutissime olivaceo-griseae, $20-23 \mu$ longae, cellula superiore $7 \cdot 5-9 \mu$ longa et lata, inferiore $12 \cdot 5-15 \mu$ longa ad septum ca. $7 \cdot 5-8 \mu$ lata.

Hab. in foliis Tricalysiae lanceolatae, Umtentweni, Natal, leg. Wager 32676.
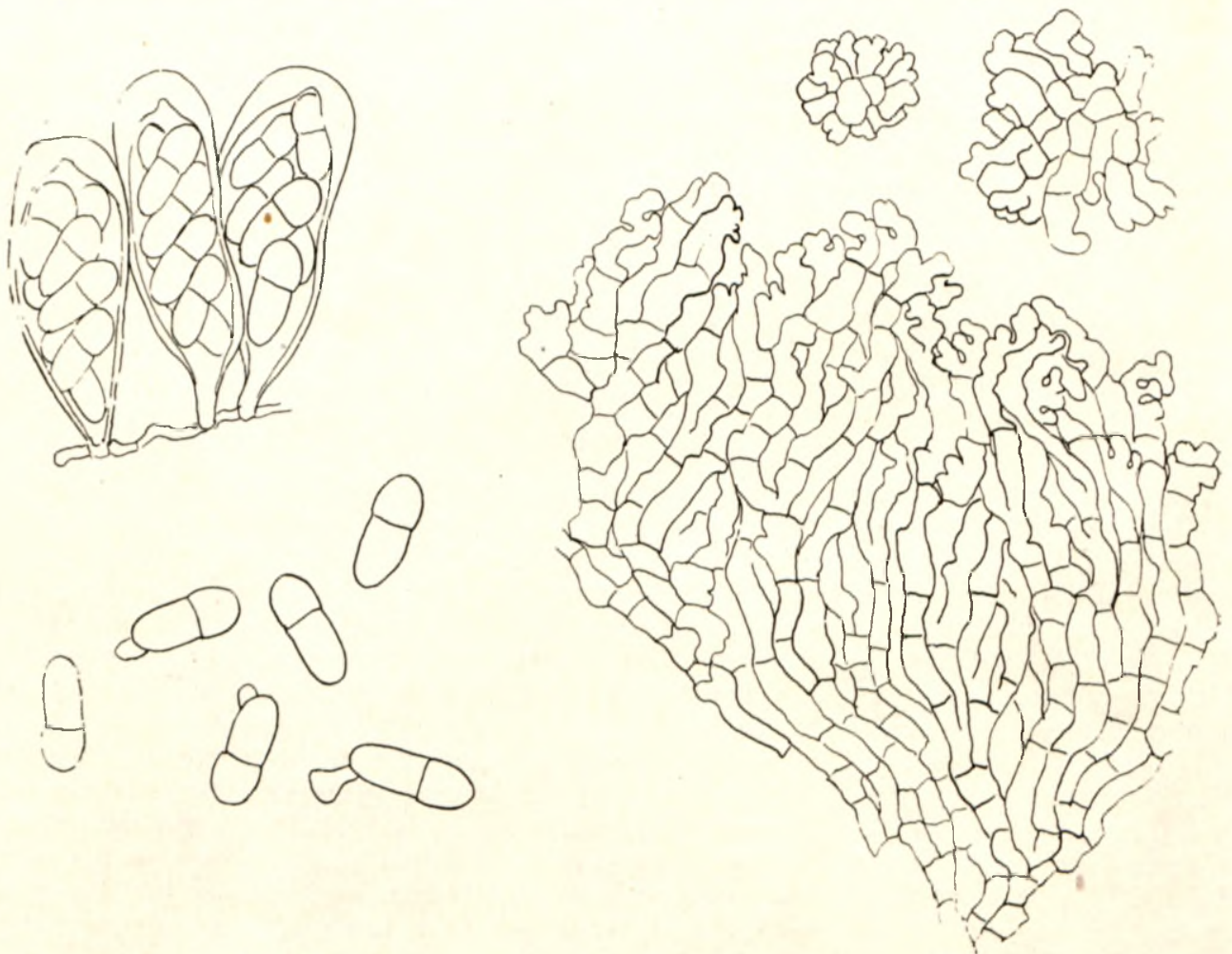

Fig. 7.-Protothyrium Tricalysiae, part of the edge of the covering membrance and two very young ascoma ta; asci ; spores.

Free mycelium none. Stromata amphigenous, mostly epiphyllous, forming superficial crusts, more or less round to irregular in outline and up to $4 \mathrm{~mm}$. diam., dull black, scattered, sometimes becoming confluent.

Covering membrane raised above the leaf surface to a height of $75 \mu$, flat at the margins. The central part is opaque black and structure not readily discernible; it consists of more or less radiating or winding rows of cells and at maturity cracks irregularly, breaking into uneven fragments ; the margin of the covering membrane is irregular in outline and consists of irregularly radiating hyphae, which are more or less translucent, buffy-brown, tortuous and subtorulose, $4-6 \mu$ thick with cells of uneven length, $12 \cdot 5-20 \mu$ long. 
In contact with the cuticle of the leaf, there is a thin hypothecium, continuous throughout the stroma, deep to dark olive-buff and apparently consisting of a single layer of cells 5-6 $\mu$ thick. This is connected at many points, through the cuticle, with the hyalive epidermal hypostroma, which consists of closely interwoven hyphae $2 \cdot 5-3 \mu$ thick, filling the epidermal cells under the whole external stroma. From the epidermal hypostroma, fine hyphae penetrate more deeply into the leaf. Not infrequently a second stroma develops on the under side of the leaf, opposite to that on the upper surface; this seems to indicate that the mycelium may penetrate through the leaf without extending laterally to any distance.

The hypothecium gives rise to very numerous asci, which are not grouped in loculi, but stand erect in the stroma. There are no definite paraphyses between the asci and the structure of the intervening tissue is not readily discernible ; it is brownish, and shows traces of a thread-like structure, having apparently broken down early into an almost structureless, greyish-olive, mucous mass.

Asci ovate to oblong-clavate, 8 -spored, broadly rounded above, usually tapering slightly or more decidedly to the base, occasionally obovate and broader at the base, sessile or with a short, peg-like foot, with a firm wall, thickened round the apex to 5-6 $\mu, 50-60 \times 20-25 \mu$. Spores more or less distichous, oblong or oblong-clavate, broadly rounded above, tapering gradually and slightly towards the rounded base, l-septate, not constricted or very slightly so, smooth, long remaining hyaline, slightly tinted, smoke-grey at maturity, $20-23 \mu$ long: upper cells shorter and broader, 7.5-9 $\mu$ long and broad, lower $12 \cdot 5-15 \mu$ long, ca. $7 \cdot 5-8 \mu$ broad at the septum and tapering somewhat downwards; often germinating from the basal end in the ascus.

The stromata readily become detached from the leaf, or the central part may fall away, exposing somewhat discoloured leaf tissues surrounded by the margin of the stroma.

on Tricalysia lanceolata Schum., on leaves, Umtentweni, Wager 192, 32676 ; Louis Trichardt, V. A. Putterill, 11825 ; Woodbush, Doidge, 1782 ; Eshowe, Laughton, 33554 .

The earlier collections of this fungus were immature.

\section{Cyclotheca Bosciae Doidge.}

Bothalia I, Part 4 (1924), 196.

The type specimen of this fungus is in rather poor condition, and spores examined were not quite mature; they are said to be hyaline, $11 \cdot 6-13 \cdot 3 \times 8 \cdot 3 \mu$; the figure for width, $8 \cdot 3 \mu$, is obviously a clerical error, $5 \cdot 3$ being intended.

A more recent collection on the same host provides more abundant and more mature material ; the spores become fuscous when fully ripe and are $12-16 \times 5-6 \mu$. This fungus has also been found in the north-eastern Transvaal on Maerua Legatii Burtt Davy.

In the genus Cyclotheca the spores are hyaline; this fungus with light brown spores must therefore be transferred to the genus Hysterostomella and becomes:-

Hysterostomella Bosciae Doidge nov. comb.

Syn. Cyclotheca Bosciae Doidge 1.c.

on Maerua racemulosa (A.P.DC.) Gilg. and Ben. (= Boscia caffra Sond.), Ebb and Flow, Wilderness, Doidge, 17125, Type ; Knysna, Laughton, 32839.

Maerua Legatii Burtt Davy, near Olifants River on the road from Tzaneen, Pilgrims Rest Distr., Scott, 34028.

The genus Hysterostomina, differs from Hysterostomella only in the presence of paraphyses in the mature ascomata, a character now not admitted as a generic distinction. Hysterostomina spp. must therefore be included in the genus Hysterostomella and the following South African fungi are affected by the change in nomenclature :- 


\section{Hysterostomella tenella Syd.}

Ann. Myc. 10 (1912) p. 442.

Hysterostomina tenella Syd. in Theissen and Sydow, Ann. Myc. 13 (1915) p. 228. on Asparagus striatus Thunb., Despatch, Doidge, 1241.

243. Hysterostomella Oxyanthae Doidge nov. comb.

Hysterostomina Oxyanthae Doidge, Bothalia 2 (1927) p. 232.

Morenoella Oxyanthae Doidge, Trans. Roy. Soc. S. Africa 8 (1920) p. 286.

on Oxyanthus Gerrardi Sond., Woodbush, Doidge, 1758, 17725, 28340.

244. Hysterostomella opaca (Syd.) Doidge nov. comb.

Hysterostomina opaca Syd., Ann. Myc. 22 (1924) p. 429.

on Olea foveolata E. Mey., Knysna, van der Byl 1397, 2280.

The genus Palawania was characterised by Sydow [Phil. Journ. Sci. (C) Botany, Vol. IX (1914) 171 and Ann. Myc. 13 (1915) p. 249] as follows :-

"Stromata superficialia, carbonacea, radiato-contexta, ex hypostromate subepidermali per stromata erumpenti oriunda, hypothecio tenui. Loculi rotundati, discreti. Asci paraphysati, octospori. Sporae phaeodidymae."

Two species were described.

Palawaniella [Doidge, Bothalia I (1921) p. 16] was said to differ from Palawania in the centrifugal arrangement of the stromata and in the epidermal rather than sub-epidermal hypostroma.

Hansford has re-examined the two species of the genus Palawaniella and reports that: "In Palawaniella orbiculata (Syd.) Doidge, the hypostroma consists of dark hyphae filling individual epidermal cells and connected with the ascoma by fine filaments and with each other by hyaline hyphae through and below the epidermis ; a few hyphae penetrate into the sub-epidermis."

"In Palawaniella Dovyalidis Doidge, the hypostroma is similar to that of $P$. orbiculata but with more penetration of the palisade tissue by the sub-epidermal hyphae."

It is obvious that the degree of penetration of the tissues by the hypostroma cannot ne maintained as a generic distinction, nor is the centrifugal development of the stromata of any great significance. As indicated by Hansford (I.M.I. No. 15, 1946, p. 168.) in his key to genera of the Polystomellineae, the genus Palawaniella Doidge should be united with the genus Palawania Sydow, which consists of species with 2-celled, coloured spores and ascomata attached at several points, hymenia under distinct scutella and irregularly arranged; there is no free mycelium.

The synonymy and host range of the South African species would then be as follows :-

245. Palawania orbiculata (Syd.) Doidge.

Seynesia orbiculata Syd., Ann. Myc. 10 (1912) p. 39.

Palawaniella Eucleae Doidge, Bothalia I (1921) p. 16.

Hysterostomina Eucleae (Doidge) van der Byl, S. Afric. Journ. Sci. 22 (1925), p. 192.

Palawania Eucleae (Doidge) Nel, Ann. Univ. Stellenbosch XX A 2 (1942) p. 22.

Palawaniella orbiculata (Syd.) Doidge, Bothalia IV (1942), p. 329.

on Euclea lanceolata E. Mey., Piesanghoek, Bosman, 25868; Rooiwal, Bosman, 29922.

Euclea macrophylla E. Mey., Howieson's Poort, Doidge, 12375.

Euclea natalensis A.DC., Letaba Drift, Doidge, 1808; New Agatha, 11384; Nelspruit, Liebenberg, 29910. 
Euclea racemosa Murr., Cape Flats, Dippenaar, 33885.

Euclea spp., Knysna, Bottomley and Laughton, 32248; Grahamstown, Otto (Stell. 348).

246. Palawania Dovyalidis (Doidge) Nel.

Ann. Univ. Stell. XX A 2 (1942), p. 22.

Palawaniella Dovyalidis Doidge, Bothalia I (1924), p. 98.

on Dovyalis rhamnoides Harv., The Wilderness, Doidge, 17117 ; Bathurst Distr., Doidge, 12347 ; Knysna, Laughton, 32267, v. d. Byl 2297 ; George, Verwoerd (Stell. 347).

The genus Byliana Dippenaar [Ann. Univ. Stell. VIII, A 2 (1930), p. 31, Illustr. 3] is said to differ from Palawaniella in its darker hypothecium and scattered stromata. As indicated above, the arrangement of the stromata does not seem to be of any great significance; the hypostroma of Byliana Halleriae is similar to that of Palawania orbiculata. The colour and thickness of the hypothecium can hardly be regarded as a generic character. It is proposed, therefore, that the genus Byliana be united with Palawania. The species on Halleria then becomes:-

247. Palawania Halleriae (Dipp.) Doidge nov. comb.

Byliana Halleriae Dippenaar, Ann. Univ. Stell. VIII (1930), p. 32.

on leaves of Halleria lucida Linn., Bloukransrivier, $v$. d. Byl 2496, 33592 ; Knysna, Verwoerd (Stell. 345).

I am indebted to Dr. Dippenaar for the opportunity of examining the type specimen.

\section{Asterodothis solaris (Kalchbr. and Cooke) Theiss.}

The genus Asterodothis was established by Theissen [Ann. Myc. 10 (1912), p. 179] for the fungus described by Kalchbrenner and Cooke [Grevillea 9 (1880), p. 35] as Asterina solaris on Olea verrucosa.

In Annales Mycologici 13 (1915), p. 232, Theissen and Sydow cited as a synonym Lembosia Albersii P. Henn. on Elaeodendron; the latter specimen has not been seen, but in Bothalia I (1921), p. 10, the writer included a number of collections of a fungus on Elaeodendron under this species. The spores are similar and there is a general resemblance in habit, but a more careful study shows that the fungus on Cassine (=Elaeodendron) is not Asterodothis but a dense form of the fungus described by Sydow as Asterinella dissiliens and later transferred to the genus Asterina [Bothalia IV (1942) p. 287] because of the presence of hyphopodia. (See also Hansford, l.c. p. 190.).

It seems that in South Africa at least, Asterodothis solaris occurs only on species of Olea; the organs described as hyphopodia in some instances and in others regarded as rudimentary setae or bristles, are conidiophores. There are no true hyphopodia on the mycelium of $A$. solaris.

\section{Polyrhizon Pterocelastri Doidge nov. spec.}

Stromata amphigena, plerumque epiphylla, irregulariter laxeque sparsa, sine maculis, ambitu sat regulariter orbicularia, $1-4 \mathrm{~mm}$. diam., raro confluendo irregularia et majora, e pluribus ascomatibus irregulariter circinantibus concreta, ex hypostromate subepidermale ubique sub stromate evoluta oriunda. Ascomata partialia dense conferta, orbicularia, usque $800 \mu$ diam., pede centrali 35-60 $\mu$ lato, atrobrunneo, epidermide innata, strato tegente intense et opace atra, ad peripheriam e hyphis radiantibus subtortuosis leniter undulatis, 4-5 $\mu$ crassis contexto. Hypothecium fuscum, minute cellulosum. Loculi pauci, annulatim circa pedem ordinati, $80-100 \mu$ alti, $150-300 \mu$ diam. Asci sat numerosi, ovati v. ellipsoidei, raro clavati, antice late rotundati, sessiles v. brevissime pedicellati, 8-spori, 
66-80 $\times 22 \cdot 5-38 \mu$. Sporae distichae, intense olivaceo-brumneae, oblongo-clavatae utrinque rotundatae, 1-septatae, constrictae, $27 \cdot 5-33 \mu$ longae, cellula superiore ellipsoidea, 15-16.5 $\mu$ longa, 10-12.5 $\mu$ lata, inferiore oblonga $\mathrm{v}$. subcuneata $12 \cdot 5-16 \cdot 5 \mu$ longa ad septum 7.5-10 $\mu$ lata. Paraphyses persistentes filiformes, ascos superantes, ca. $1.5 \mu$ crassae, ad apicem clavato incrassatae usque $2 \cdot 5 \mu$ latae.

Hab. in foliis Pterocelastri Galpini, Kromrivier, leg. Doidge et Bottomley, 32776.

Mycelium almost entirely sub-epidermal, composed of hyphae 2-2.5 $\mu$ thick; these become much branched and closely interwoven, forming an extensive and more or less dense hypostroma in the palisade cells; from the hypostroma, hyphae grow out and penetrate into the mesophyll of the leaf, often reaching the lower epidermis. The hypostroma becomes particularly dense in the sub-stomatal cavity; here it becomes blackish-brown and emerges through the stomata to the leaf surface at many points. These form the starting points of the partial stromata which develop centrifugally in round, crowded groups.

The compound stromata are mostly epiphyllous, scattered, $1-4 \mathrm{~mm}$. diam., rarely confluent. The individual or partial stromata are round, up to $800 \mu$ diam., with a blackishbrown, opaque central foot, $35-60 \mu$ broad, connecting with the hypostroma. The covering membrane is deep black, opaque, carbonaceous and very brittle; at the sterile margin, which lies flat on the leaf surface or overlaps that of a neighbouring partial stroma, the radiating structure is more or less evident ; it consists of radiating, pellucid brown, branching, somewhat undulating, tortuous hyphae, 4-5 $\mu$ thick. Hypothecium ca. 15-20 $\mu$ thick, fuscous to olive-brown, minutely cellular.

Loculi few, arranged in a circle round the central foot, $80-100 \mu$ high in the centre, $150-300 \mu$ diam. Asci fairly numerous, ovate or ellipsoid, rarely clavate, broadly rounded above, sessile or very briefly pedicellate, 8 -spored, $66-80 \times 22 \cdot 5-38 \mu$. Spores distichous, deep olive-brown when mature, clavate-oblong, rounded at both ends, 1-septate, deeply constricted, 27.5-33 $\mu$ long; upper cell ellipsoid, 15-16.5 $\mu$ long and 10-12.5 $\mu$ broad; lower oblong or subcuneate, $12 \cdot 5-16 \cdot 5 \mu$ long, $7 \cdot 5-10 \mu$ broad just below the septum and tapering somewhat downwards. Paraphyses persistent, filiform, exceeding the asci, about $1 \cdot 5 \mu$ thick, up to $2 \cdot 5 \mu$ thick at the clavate tips.

on Pterocelastrus Galpini Loes., Kromrivier, Rustenburg Distr., Doidge and Bottomley, 32776.

The two species of Polyrhizon previously described on South African hosts are Polyrhi.on Bewsii Doidge on Cassine spp., and P. Celastri on Gymnosporia acuminata Szysz. : all three species occur on host genera belonging to the family Celastraceae.

\section{Echidnodes Curtisiae Doidge nov. spec.}

Epiphyllum, maculas orbiculares, sparsas, sat regulares, plerumque acute marginatas usque $7 \mathrm{~mm}$. diam., in epiphyllo brunneas, zonula angusta atro-brunnea cinctas, in hypophyllo decolorationes flavo-brunneolas efformans. Mycelium intramatricalium profunde in mesophyllum penetrante, hypostromate fusco subepidermale efformans. Plagulae epiphyllae in centro maculae parum perspicuae. Mycelium liberum parce evolutum ex hyphis radiantibus laxe reticulatis, olivaceo-brunneis, sub-rectis v. curvatis, obscure septatis, $2 \cdot 5-5 \mu$ plerumque 4 u crassis compositum. Hyphopodia pauca, sparsa, continua, subglobosa v. pyriformia, 4-5 $\mu$ alta et lata. Thyriothecia pauca in centro maculae laxe dispersa, linearia, recta v. curvata, $350-1,000 \mu$ longa, $150-200 \mu$ lata, strato tegente convexulo, atro-brunneo, in parte centrali opaco, marginem versus ex hyphis radiantibus $2-3 \mu$ crassis composito, margine haud fimbriato, rima longitudinali dehiscentia, membrana basali olicaceobrunnea ex cellularum sat indistinctarum composita hypostromate subepidermali pluries affixa. Asci ovati sessiles, 8-spori, 30-33 × 15-17.5 $\mu$. Sporae conglobatae, brunneae, oblongae $\mathrm{v}$. subclavatae, utrinque rotundatae, 1 -septatae, leniter constrictae, $15-17 \times 5-6 \mu$.

Hab. in foliis Curtisiae fagineat, Deepwalls, Knysna, leg. Bottomley, 32131 a.

Causing scattered, more or less circular leaf spots, up to $7 \mathrm{~mm}$. diam.; on the upper side of the leaf these are seal-brown with blackish-brown border; on the under side they are paler, army-brown to buffy-brown. 
In the discoloured areas, the mycelium penetrates deeply into the host tissues. Lighthrown hyphae, beneath the thyriothecia, form a sub-epidermal plate, which is connected with the basal nembrane of the thyriothecia at many points by hyphae passing through the stomata, or between the epidermal cells and through the cuticle.

Superficial mycelium epiphyllous, rather sparse, radiating from the centre of the leaf spot, loosely reticulate, dark olive-brown to buffy-brown, almost straight or more or less curved, obscurely and rather frequently septate, uneven in thicknesi, $2 \cdot 5-5 \mu$ thick, mostly $4 \mu$. There are a few scattered hyphopodia, l-celled, sub-globose or oval to pyriform, 4-5 $\mu$ high, 4-5 $\mu$ broad.

Thyriothecia epiphyllous, few, in the centre of the leaf spot and of the superficial mycelium, linear, $350-1,000 \mu$ long, straight, curved or bent, $150-200 \mu$ broad, $60-65 \mu$ high in the centre. Covering membrane black, opaque, except at the margin, where it is formed of radiating hyphae, $2-3 \mu$ thick ; margin irregular but not fimbriate ; dehiscing at maturity by an irregular, longitudinal fissure almost the length of the covering membrane. Basal membrane olive-brown, structure obscure. Asci ovate, sessile, 8-spored, $30-33 \times 15-17 \cdot 5 \mu$. Spores conglobate, buffy-brown, sub-cylindrical to sub-clavate, rounded at both ends, 1-septate, slightly constricted at the septum, 15-17 $\times 5-6 \mu$; loculi sub-equal in length or the upper slightly shorter and broader, the upper loculus sub-ovate, broader near the septum, the lower cylindrical. When the spores germinate, a hyphopodium is formed near the septum.

on leaves of Curtisia faginea Ait., associated with Meliole ganglifere Kalchbr., Deepwalls, Knysina, A. M. Bottomley, 32121 a.

Although a few hyphopodia are present, the extensive internal mycelium seems to place this fungus in the genus Echidnodes; compare Hansford's notes on Lembosia durbana v. d. Byl (Bothalia IV, p. 820.)

\section{Echidnodes transvaalensis Doidge nov. ip.}

Plagulae epiphyllae, atrae, sparsae, ambitu irregulares, usque ca. $2.5 \mathrm{~mm}$. diam., haud acute definitae. Mycelium ex hyphis plus minus undulatis, dilute olivaceo-brumneis, indistincte septatis, $2-2 \cdot 5 \mu$ crassis compositum. Thyriothecia plerumque dense dispersa, haud raro dense conferta, oblonga, recta v. curvata, $200-420 \mu$ longa et $80-100 \mu$ lata, rima longitudinali dehiscentia, vel orbicularia, 80-125 $\mu$ diam.; strato basali tenui, subhyalino; strato tegente convexulo, pellucide brunneo, ex hyphis radiantibus $2-3 \cdot 5 \mu$ crassis, cellulis 3-5 $\mu$ longis composito, peripherice plus minus fimbriato. Asci numerosi, 8-spori, ovati, sessiles, forme tunicati, 22.5-35 $\times 10-12 \cdot 5 \mu$. Sporae subdistichae v. conglobatae, oblongae v oblongo-clavatae, antice late rotundatae, postice leniter attenuatae, 1 -septatae, haud vel vix constrictae, leves, dilate olivaceo-brunneae, $10-12 \cdot 5 \times 4-5 \mu$, cellula inferiore plerumque leniter angustiore.

\section{Hab in foliis Eugenine natalitiae, Mariepskop, leg. Scott, 34027.}

Colonies epiphyllous, scattered, thin, dull black, irregular in outline, poorly defined, up to $2.5 \mathrm{~mm}$. diam. Mycelium delicate, radiating irregularly and becoming loosely reticulate, ahyphopodiate. Hyphae light grevish-olive or grevish-olive to dark olive-buff, $2-2 \cdot 5 \mu$ thick, more or less undulating, not infrequently ruming parallel to one another and forming loose strands of 2 or 3 hyphae; branching irregular; septation obscure and rather distant.

Thyriothecia fairly numerous, crowded in irregular groups, often becoming confluent; single thyriothecia linear oblong, straight, curved, bent at almost a right-angle or forked, $20(0)-420 \mu$ long and $80-100 \mu$ broad, dehiscing by an irregular longitudinal crack, rumning almost the whole length of the covering membrane; or more or less circular in ontline, 80-125 $\mu$ diam., dehiscing by irregular cracks radiating from a central pore. Basal membrane delicate, structure not evident. Covering membrane slightly convex, at first dark olive-buff, becoming olive-brown, more or less pellucid, hut sub-opaque in the centre; 
composed of radiating hyphae $2-3.5 \mu$ thick, with cells $3-5 \mu$ long; margin more or less fringed, the fringing hyphat not differing from those of the mycelium.

Asci very numerous, ovate, broadly rounded above, sessile or with a short peg-like foot, 8-spored, $22 \cdot 5-35 \times 10-12 \cdot 5 \mu$, with a firm wall slightly thickened round the apex. Paraphyses breaking down early into an olivaceous mass without recognisable structure. Spores imperfectly distichous to conglobate, 1-septate, oblong to oblong-clavate, grevisholive, $10-12 \cdot 5 \times 4-5 \mu$, smooth, not constricted at the septum or barely so, broadly rounded above, tapering somewhat to a rounded base; loculi more or less equal in length, but the upper slightly broader than the lower.

on leaves of Eugenia nalatitia Sond., Mariepstiop, Pilgrims Rest district, E. Scott, 31027.

This fungus, which is very similar in habit to Lembosia Wageri Doidge, is very closely associated, on the same leaves with Asterina natalitia Doidge.

\section{Morenoina Dracaenae Doidge nov. spec.}

Epiphylla, maculas rufo-brunneas ellipticas v. suborbiculares usque $10 \mathrm{~mm}$. longas, 6-8 mm. latas efficiens. Mvcelium liberum nullum, intra-matricalium subcuticulare, radiante ex hyphis hyalini v. fuscis, $2-4 \mu$ crassis septatis cellulis $5-15 \mu$ longis compositum Ascomata numerosa, densiuscule et centrice dispersa, haud raro 2-3 dense conferta et plus minus connata, primitus ambitu orbicularia vel elliptica, mox elongata oblonga, recta v. curvata, $170-500 \mu$ longa, $150-200 \mu$ lata, 70-85 $\mu$ alta, primo clausa dein rima longitudinale dehiscentia; strato tegente convexulo, opace atro-brunneo, marginem versus radiatim contexto ex hyphis $2 \cdot 5-4 \mu$ crassis contexto, peripherice copiose breveque fimbriato; strato basali subhyalino, $3-4 \mu$ crasso. Asci 8-spori, ovati, 30-35 $\times 22-25 \mu$ v. oblongoclavati $40-50 \times 15-20 \mu$, antice late rotundati, deorsum sensim attenuati sessiles. Sporae distichae v. imperfecte tristichae, oblongo-clavatae, utrinque late rotundatae, leves, 1-septatae, constrictae, diu hyalinae tandem olivaceo-brunneae, $20-22 \cdot 5 \mu$ longae, cellula superiore ovata, 9-10 $\mu$ longa, 6-7.5 $\mu$ lata, inferiore oblonga $v$. basim sensim attenuata, $11 \cdot 5-12 \cdot 5 \mu$ longa 5-6 $\mu$ lata.

Hab. in foliis Dracuenae Hookeriance, Durban, leg. P. A. van der Byl (v. d. Byl 328).

The fungus causes reddish-brown leaf spots on the upper side of the leaf ; these are elliptic to sub-circular in outline, up to $10 \mathrm{~mm}$. long and $6-8 \mathrm{~mm}$. I, road. On the under side of the leaf there is no discolouration of the tissues, but they are concave under the leaf spots.

There is no superficial mycelium, but the thyriothecia are attached either in the centre, or at several points, to a sub-cuticular mycelium. This takes the form of sub-cuticular plates, one cell thick, hyaline to dark olive-buff and buffy-brown. It consists of straight or curved hyphae, $2 \cdot 5-4 \mu$ thick, with cells $5-15 \mu$ long and rather frequently branched; through repeated branching the hyphae, which are fused by their lateral walls, form a radiating fan-shaped structure at the edge of the colony.

Ascomata epiphyllous, developing in concentric rings, very numerous, often crowded and becoming coalescent in groups of $2-3$ or more; at first romd to elliptic in outline, becoming oblong to oblong-linear, rounded at both ends, straight, curved or bent, 170$500 \mu$ long, $150-209 \mu$ broad, $70-85 \mu$ high in the centre. Covering membrane convex, blackish-brown, opaque, visibly radiating in structure towards the margin, briefly and densely fimbriate, consisting of hyphae $2 \cdot 5-4 \mu$ thick; at maturity splitting down the centre to form a longitudinal fissure running almost the length of the covering membrane; less frequently developing radiating cracks. Basal membrane sub-hyaline, 3-4 $\mu$ thick; structure not evident. Asci numerous, 8-spored, ovate, $30-35 \times 22-25 \mu$, or oblongclavate, 40-50 $\times 15-20 \mu$, the ovate asci being near the margin of the ascomata and the more elongated asci near the centre. Asci broally rounded above, more or less tapering to the base, sessile, thin-walled, slightly thickened, up to $5 \mu$, round the apex. Spores distichous or imperfectly tristichous, clavate-oblong, broadly rounded at both ends, smooth, long remaining hyaline, becoming dark olive-buff to buffy-brown, 1-septate, constricted 
at the septum, 20-22.5 $\mu$ long; upper cell ovate, 9-10 $\mu$ long, $6-7 \cdot 5 \mu$ broad ; lower cell oblong or tapering slightly downwards, $11 \cdot 5-12 \cdot 5 \mu$ long, $5-6 \mu$ broad; the cells separate rather readily at the septum.

on leaves of Dracaena Hookeriana K. Koch, Durban, van der Byl 3:8.

\section{Bulliardella capensis Doidge nov. spec.}

Hysterothecia erumpenti-superficialia, carbonacea, sparsa vel gregaria, elliptica v. rotundata, utrinque obtusa, 400-750 $\mu$ longa, 400-500 $\mu$ lata, extus atra subnitentia rima longitudinali percursa, haud carinata. Asci 6-8 spori, cylindracei v. clavati, apice rotundati, tenuiter tunicati, $125-150 \times 20-30 \mu$, paraphysibus filiformibus, ramosis. Sporae recte $v$. oblique distichae, olivaceae, cylindraceae, utrinque rotundatae, 1-septatae, medio leniter constrictae, $47 \cdot 5-52 \cdot 5 \times 11 \cdot 5-13 \mu$, loculo superiore longiore et lenissime latiore.

Hab. in ramulis Gymnosporiae procubentis, Qolora, Transkei, leg. M. Gunn, 24136.

Hysterothecia scattered or more or less gregarious, erumpent to superficial, carbonaceous, shining black, elliptic to circular in outline, 400-750 $\mu$ long, 400-500 $\mu$ broad ; flattened elliptic in section and about $350 \mu$ high ; traversed by a narrow longitudinal fissure, lips level or slightly incurved, not ridged. Walls thick, opaque, $50-75 \mu$ thick at base and sides, becoming thinner above. Asci numerous, 6-8-spored, cylindrical to clavate, broadly rounded above, tapering at the base, or constricted abruptly into a short peg-like foot, thin-walled, 125-150 × 25-30 $\mu$. Paraphyses delicate, filiform, branched. Spores subdistichous, parallel or oblique, grayish-olive to buffy-brown, cylindrical, rounded at both ends, 1-septate, slightly constricted at the septum, straight or slightly curved, $47 \cdot 5-52 \cdot 5$ $\times 11 \cdot 5-13 \mu$; upper cell longer than the lower and slightly broader, cylindrical or broadening slightly above the septum, $26 \cdot 5-29 \mu$ long; lower cell tapering somewhat to the base ; loculi separating readily at the septum.

on twigs of Gymnosporia procumbens Lees., Qolora, Transkei, M. Gunn, 34136 ; closely associated with Lecanora sp. and with other lichens; an immature hysteriaceous fungus with longer ascomata and nuriform spores was also found on the same twigs.

In "Observations on Species of Bulliardella" (Papers of Mich. Acad. Sci. Arts and Letters, Vol. 23, 1938, pp. 155-61) Lohman mentions five species of Bulliardella, of which four were previously known in Europe ; the fifth B. nitida (Ellis) Lohman is a North American species. With the exception of $B$. sphaerioides, found in Europe and North America on Betula, all are conifer-inhabiting fungi and all are comparatively small spored, with spores less than $20 \mu$ long and $7 \mu$ broad. There appears to be no previous record of this genus in the southern hemisphere. The spores of $B$. capensis are sometimes deeply constricted at the septum and the cells sub-pyriform in shape, very similar in form to those of $B$. sphaeroides, but they are much larger.

\section{Bulgariastrum africanum Syd.}

Ann. Myc. 13 (1915) p. 42.

Ascomata amphigenous and caulicolous, not on definite leaf spots, but causing an indeterminate, yellow-brown discolouration of the leaf tissues, very closely crowded in round groups, which are up to $5 \mathrm{~mm}$. diam., or occasionally becoming confluent and irregular ; not infrequently interspersed with conidiiferous stromata in the same groups; the latter are black, more or less round, pulvinate, the surface rough with many fissures and folds. The ascomata are sub-turbinate, at first gelatinous, hard and horny when dry ; disk waxy in appearance, with a raised black border. (Plate I $a$ and $b$.)

The mycelium penetrating the tissues of the host is similar in character and extent to that of Bulgariastrum bullatum, but the internal stroma and the base of the external stroma is lime-green in colour and is translucent. The stroma is $250-350 \mu$ broad at the base, expanding rapidly upwards; it may be simple, bearing one disk, branching to produce two or three disks, or with ascoma and conidia on one stroma. The ascoma expands rapidly upwards to a height of $400-500 \mu$, the expanded disk being slightly concave or slightly 
convex, varying from $300 \mu$ to $1,000 \mu$ in diameter ; disk normally round, but in closely crowded groups it becomes elliptic through mutual pressure.

The central part of the stroma is lime-green, parenchymatous in texture and composed of cells 12-18 $\mu$ diam., with a cortex of smaller cells, 7-12 $\mu$ diam., dusky blue-green in colour and externally rough and loosely connected.

Asci clavate, rounded above, 8-spored, 60-90 $\times 14-16 \mu$. Spores obliquely monostichous or incompletely distichous, hyaline, ellipsoid-oblong, 1-septate, not constricted at the septum or slightly so, rounded at both ends, $12-15 \times 6-7 \mu$; cells equal or nearly so. Paraphyses filiform, thicker $(3-4 \mu)$ at the clavate tips, exceeding the asci and forming a dense, dusky green-blue epith acium.

The conidiiferous stroma is similar in structure to the ascoma, but pulvinate in form. Under the cortical cells cavities develop, $200-300 \mu$ diam. and $200-300 \mu$ high ; the surface of the cavity, on all sides, is lined with conidiophores, which are simple, straight or slightly curved, cylindrical, ca. 10-13 $\mu$ long and 2-2.5 $\mu$ thick. Conidia borne singly at the tips of the conidiophores, hyaline, mostly clavate, rarely ellipsoid, straight or slightly curved, not tapering or tapering slightly to the rounded apex, tapering gradually towards the base, 11-25 $\times 3-5 \mu$; at first 1-septate, then 2-3-septate, often slightly constricted at the septa.

on Capparis Rudatisii Gilg. and Ben., Somerset East, MacOwan 12\%3 b, 20814 ; East London, Doidge, 12395.

The type specimen (Sydow l.c.) was collected by Rudatis 1388 at Friedenau in Natal.

The conidial form is:-

Oncospora viridans Kalchbr. and Cooke.

Grevillea IX (1880), p. 19.

Nannfeldt, Nov. Act. Reg. Soc. Sc. Upsala, Ser. IV, Vol. 8 (1932), p. 86.

Sphaeropsis abnormis Berk and Thuem. in Thuem. Myc. Univ. No. 1675.

Ephelis viridans (Kalchbr. and Cooke) Sacc. Syll. Fung. III (1884), p. 691.

Sphaeropsis enormis Sacc., Syll. Fung. X (1892), p. 254.

The host of MacOwan's collections was said to be Capparis Gueinzii, but a careful comparison with authentically named specimens shows that it is C. Rudatisii; ascomata are present on the portion of the type collection of Oncospora viridans (MacOwan 1273 b) in the Pretoria herbarium. Conidia have also been found on :-

Capparis Rudatisii Gilg. and Ben., Olifantshoek, Uitenhage, MacOvan (Sphaeropsis abnormis in Thuem. Myc. Univ. 1675); Alexandria, Iooidge, 22373.

Ascomata are formed more freely than those of Bulgariastrum bullatum, which is usually found in the conidial stage.

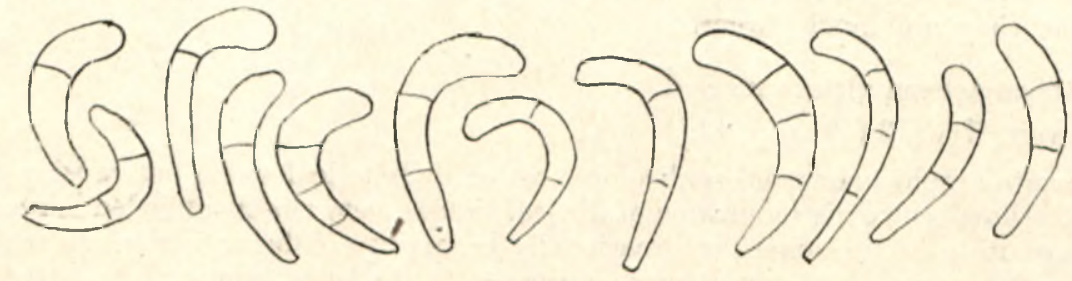

(a)

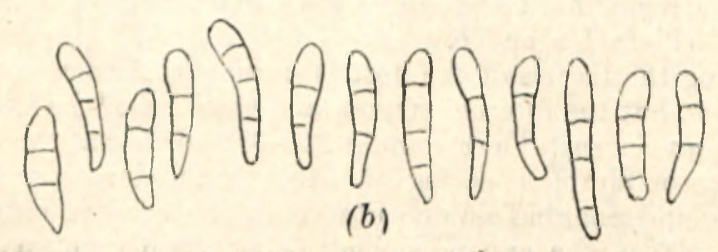

Frc. 8.-Conidia of (a) Bulgariastrum bullatum, and (b) B. africanum. 
255. Bulgariastrum bullatum Doidge nov. spec.

Ascomata hypophylla et caulicola, in epiphyllo maculas rufo-brumneas usque $5 \mathrm{~mm}$ latas leniter depressas efformantia, dense caespitosa et greges orbiculares $4-5 \mathrm{~mm}$. latos vel confluendo irregulares formantia, in stromata pulvinata erumpenti superficialia oriunda, subsessilia v. basi brevissime stipitiformi contracta, subturbinata, glabra, gelatinea, in sicco cornea, atra, disco leniter concavo dilute brunneo, 500-800 $\mu$ lato; contextu parenchymatico ex cellulis rotundatis 10-15 $\mu$ diam. composito. Asci clavati, apice rotundati, basi pedicellati, $65-100 \mu$ longi, 12-14 $\mu$ lati, octospori. Faraphyses filiformae, sursum clavato incrassatae $(2 \cdot 5-4 \mu)$ et epithecium densum flavo-fuscidulum formantes. Sporae oblique monostichae v. subdistichae, clavato-ellipsoideae, 1-septatae, leniter constrictae, hyalinae, $12 \cdot 5-17 \cdot 5 \times 5-7 \mu$ (vix maturae) cellulae superiore plerumque late rotundata et crassiore.

Status conidiiferus Oncospora bullata Kalchbr. et Cooke.

\section{Hab. in foliis Capparidis citrifoliae, Langholm Estates, Bathurst, leg. Doidge, 12350.}

Stromata amphigenous and eaulicolous, but chiefly hypophyllous; usually crowded on leaf spots, which are up to $5 \mathrm{~mm}$. diam., scattered, or numerous and becoming confluent; most conspicuous on the upper surface, where they are reddish-brown and concave. Conidiiferous stromata in close groups on leaf spots, round to ellipsoid, pulvinate, sometimes confluent and irregular, surface rough, dull black, often with irregular folds and cracks; a few stromata often form on the upper leaf surface, opposite the densely grouped stromata on the lower surface. (Plate II.)

Ascomata closely grouped on similar leaf spots, often interspersed with the conidiiferous stromata, or at least covering the centre of the spot with a border of the latter; under a low magnification, the disk is waxy in appearance with a raised, blackish-brown border.

The mycelium of the fungus in the epidermal cells of the host, sends out hyphae which penetrate more deeply into the leaf tissues ; these hyphae are at first parallel, 4-6 $\mu$ thick, thin-walled, with cells $10-15 \mu$ long ; later becoming more closely septate and forming plates of angular cells $4-10 \mu$ diam. ; these are most conspicuous between the cells of the host near the lower leaf surface, but penetrate right through the leaf and produce similar plates of cells between the palisade cells on the upper side.

Under a stoma, the hyphae grow rapidly, forming a compact, stromatic mass of cells near the surface, which become thicker-walled, and are at first hyaline, then brown and sub-opaque; the epidermis is ruptured and the stroma continues to develop externally.

The conidiiferous stroma is pulvinate, 450-750 $\mu$ diam., 200-350 $\mu$ high, and the torn epidermis adheres closely to the sides of the stroma. The mature stroma consists of a blackish-brown, sub-opaque base, 150-250 $\mu$ diam., immersed in the outer cell layers of the leaf, expanding somewhat upwards and consisting of more or less parallel rows of cells 2-5 $\mu$ thick and 5-10 $\mu$ long, snuff-brown to pale fuscous in colour, pellucid, with a rough uneven cortical layer of darker irregular cells, loosely connected at the surface, globose, ellipsoid or polygonal in form and mostly 10-15 $\mu$ diam. The conidiiferous layer is formed within this cortex, which is $40-50 \mu$ thick, and which ruptures and disappears as the conidia develop. Conidiophores forming a continuous layer, simple, straight, parallel, $1 \mathrm{C}-15 \mu$ long, 2-4 $\mu$ thick. Conidia dark olive-buff in mass, singly sub-hyaline, clavate, hamate to falcate, rarely almost straight, $20-35 \mu$ long, 4-5 $\mu$ thick at the broadest point, which is about one-third of the distance from apex to base; not tapering or tapering slightly to the rounded apex, attenuated gradually to the truncate base, which is $2-2.5 \mu$ thick.

A.comata formed on a pulvinate stroma similar to that in which the conidia are produced; it usually develops from one-half of the stroma, the other half remaining sterile or producing a second ascoma or conidia. From a base $250-350 \mu$ dian., the ascoma broadens rapidly, forming an expanded disk, 500-800 $\mu$ diam., slightly concave, rarely almost flat. Asci clavate, rounded at the apex, tapering gradually to the pedicellate base, 8-spored, sp. part 60-90 $\mu$ long, $12-14 \mu$ broad, rather thin-walled, slightly thickened $(2 \cdot 5-4 \mu)$ at the apex. Paraphyses filiform, clavate and ca. $4 \mu$ thick at the apex, exceeding the asci and forming a dense, dark olive epithecium. Spores obliquely monostichous or 
incompletely distichous, clavate-ellipsoid, 1-septate, very slightly constricted, $12 \cdot 5-17 \cdot 5$ $\times 5-7 \mu$, broadly rounded above, tapering gradually to the rounded base, upper cells rather shorter and broader than the lower. The spores examined were barely mature.

on Capparis citrifolia Lam., Langholm Estates, Bathurst, Doidge, 12350.

The conidial stage, Oncospora bullata Kalchbr. and Cooke [Grevillea IX (1880) p. 19] occurs very commonly near the south and south-east coast. The following collections have been examined :- -

on Capparis citrifolia Lam., Kowie, Stent, 7789 ; Alexandria, Doidge, 22346 ; Knysma Heads, Schonland, 12512; Knysna, Bottomley, 32260, 32241 ; The Wilderness, Doidge, 17122 ; Bonza Bay, Last London, Bottomley, 28680 ; Kingwilliamstown, Weale (ex Herb. MacOwan) 20806 ; Port Alfred, Wager, 28827 ; Grahamstown, Hansford, 33476; Kusaga Riv., Archibald, 33522 ; Bushmans River Mouth, Archibald, 33521.

Capparis Flanagani Gilg. and Ben., Boschberg, MacOwan 12\%3, 20982 ; Bushmans River, Archibald, 33523.

Capparis Gueinzii Sond., Uitenhage, Pienaar, 2362.

MacOwan 23, the type collection of Oncospora bullata is on Capparis citrifolia; his second collection, MacOwan 1273 was said to be on Capparis Gueinsii, but the portion of this collection in the Pretoria Herbarium appears to be on $C$. Flanagani, which was formerly included in $C$. Gueinzii.

The genus Bulgariastrum as at present known, comprises three species, all on leaves of Capparis spp. B. bullatum is closely related to B. africanum but appears to be quite distinct; the blue-green colour of the latter species is distinctive, and the conidial forms are more widely divergent than the ascomata. The type species, B. caespitosum Syd., occurs on C. sepiaria in the Philippines; the conidial form is Oncospora caespitosa v. Hohn. Ex description, the latter species approaches $B$. bullatum, but there are numerous minor differencas, $\Rightarrow d$ no specimen of the Philippine fungus has been available for comparison. 


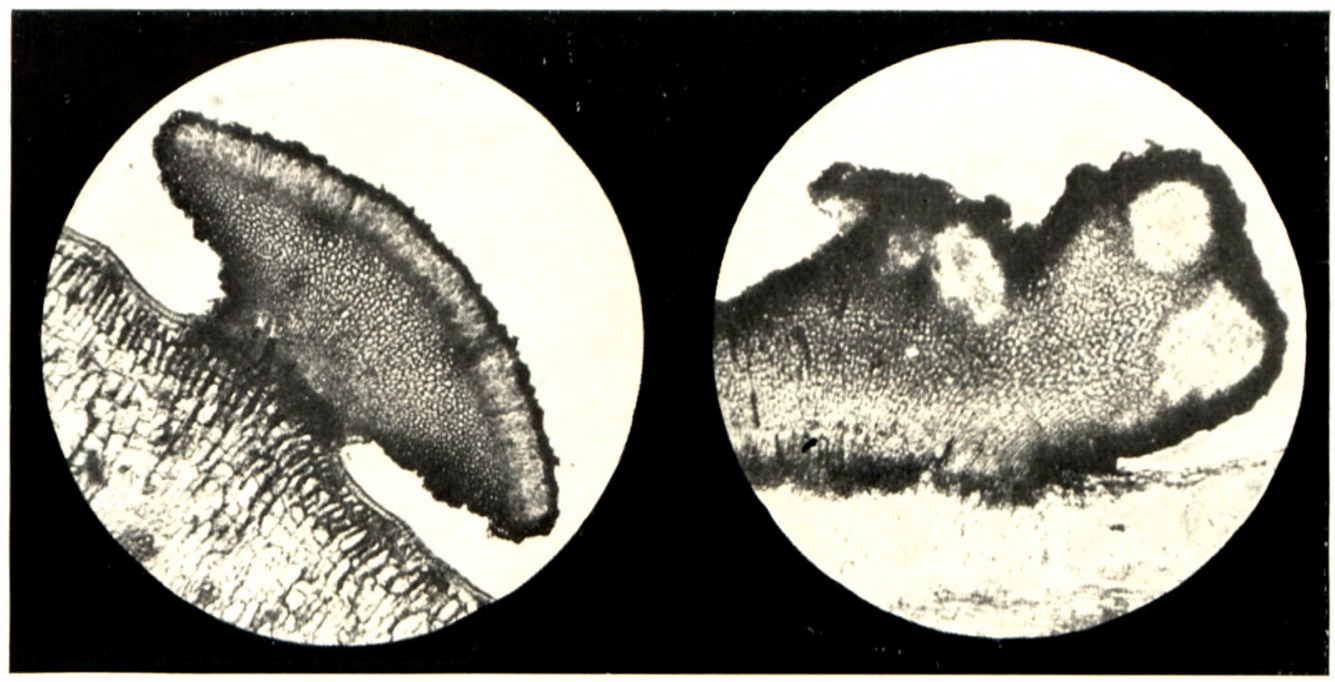

(a)

(b)

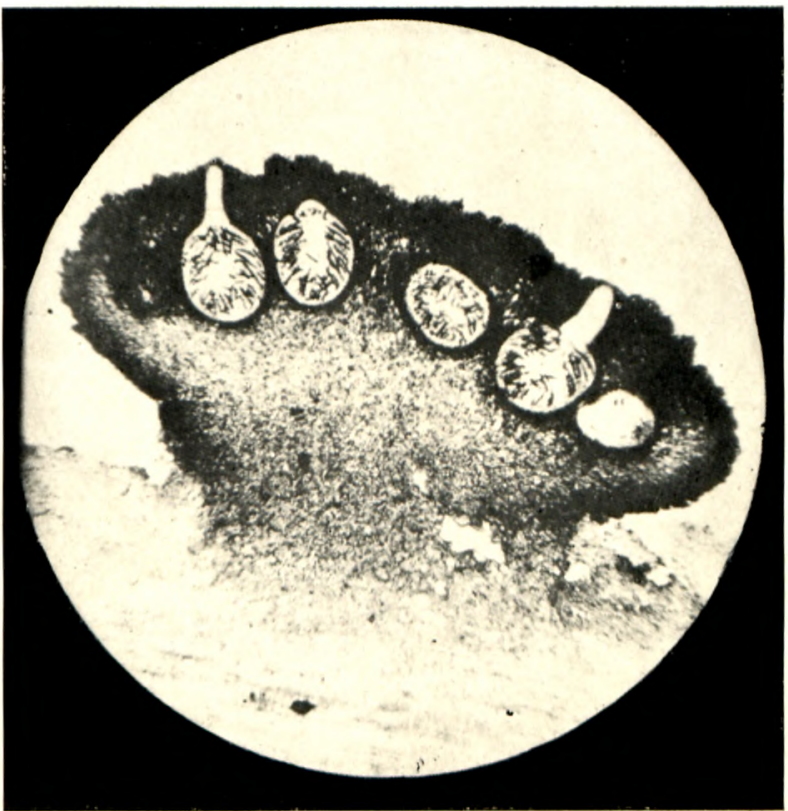

(c)

Plate I.-(a) Ascoma, and (b) condiiferous stroma of Bulguriastrum africanum; (c) stroma of Valsaria Eucalypti on Citrus. (Photo. H. A. V. King.) 


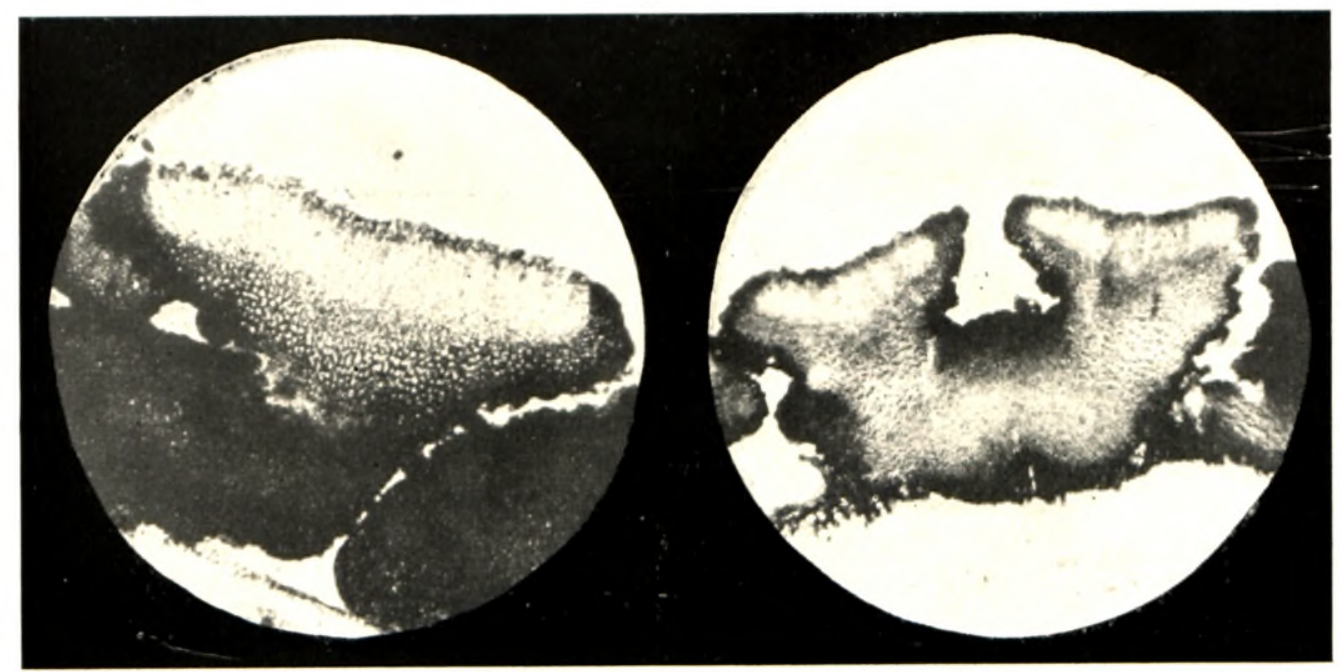

(a)

(b)

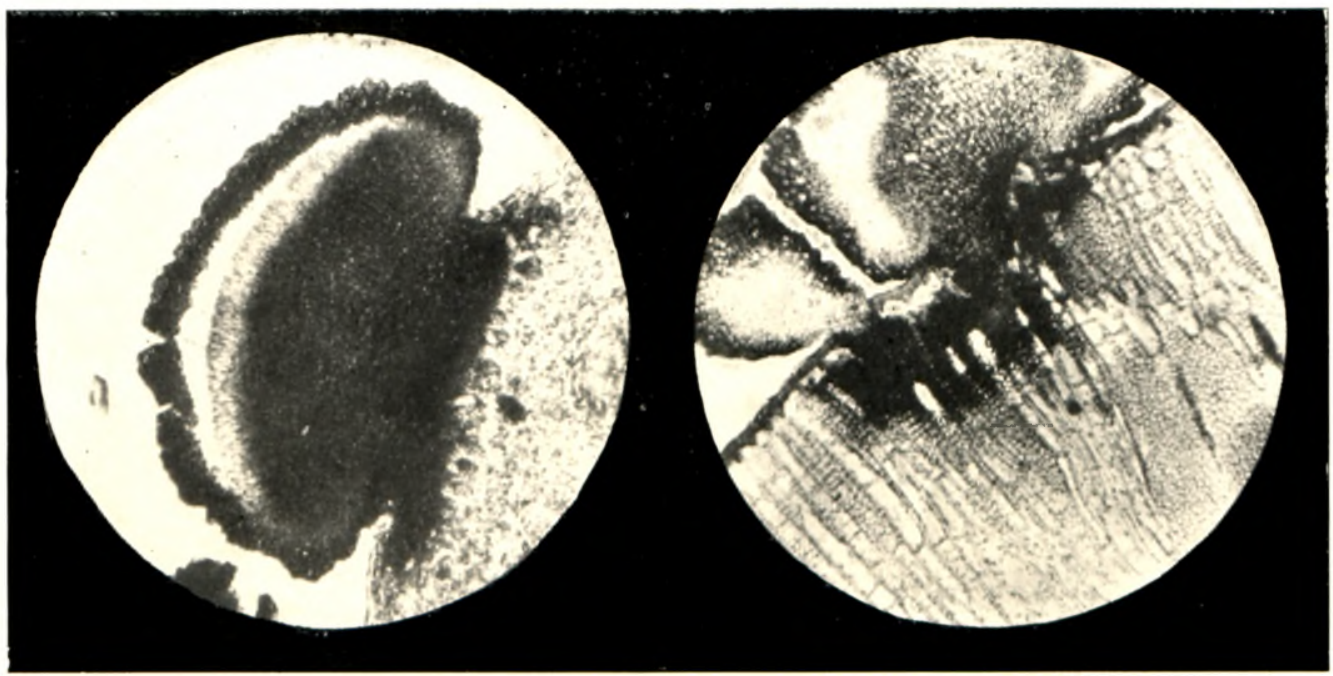

(c)

(d)

Plate II.-(a and b) Ascomata of Bulgarinstrum bullulum; (o) Conidiiferous stroma ; (d) Section through the foot of stroma and leaf, showing the mycelium in the tissues. (PHo'ro. H. A. V. King.) 